\title{
3C. 3-Ketosteroid receptors in GtoPdb v.2021.3
}

Derek Cain ${ }^{1}$, John Cidlowski ${ }^{1}$, Dean P. Edwards ${ }^{2}$, Peter Fuller ${ }^{3}$, Sandra L. Grimm ${ }^{2}$, Sean Hartig ${ }^{2}$, Carol A. Lange ${ }^{4}$, Robert H. Oakley ${ }^{1}$, Jennifer K. Richer ${ }^{5}$, Carol A. Sartorius ${ }^{5}$, Marc Tetel ${ }^{6}$, Nancy Weigel $^{2}$ and Morag J. Young ${ }^{7}$

1. National Institutes of Health, USA

2. Baylor College of Medicine, USA

3. Hudson Instiitute of Medical Research, Australia

4. University of Minnesota, USA

5. University of Colorado, USA

6. Wellesley College, USA

7. Baker Heart and Diabetes Institute, Australia

\begin{abstract}
Steroid hormone receptors (nomenclature as agreed by the NC-IUPHAR Subcommittee on Nuclear Hormone Receptors [74, 215, 3]) are nuclear hormone receptors of the NR3 class, with endogenous agonists that may be divided into 3-hydroxysteroids (estrone and 17 $\beta$-estradiol) and 3ketosteroids (dihydrotestosterone [DHT], aldosterone, cortisol, corticosterone, progesterone and testosterone). For rodent GR and MR, the physiological ligand is corticosterone rather than cortisol.
\end{abstract}

\section{Contents}

This is a citation summary for 3C. 3-Ketosteroid receptors in the Guide to Pharmacology database (GtoPdb). It exists purely as an adjunct to the database to facilitate the recognition of citations to and from the database by citation analyzers. Readers will almost certainly want to visit the relevant sections of the database which are given here under database links.

GtoPdb is an expert-driven guide to pharmacological targets and the substances that act on them. GtoPdb is a reference work which is most usefully represented as an on-line database. As in any publication this work should be appropriately cited, and the papers it cites should also be recognized. This document provides a citation for the relevant parts of the database, and also provides a reference list for the research cited by those parts. For further details see [41].

Please note that the database version for the citations given in GtoPdb are to the most recent preceding version in which the family or its subfamilies and targets were substantially changed. The links below are to the current version. If you need to consult the cited version, rather than the most recent version, please contact the GtoPdb curators.

\section{Database links}

3C. 3-Ketosteroid receptors

https://www.guidetopharmacology.org/GRAC/FamilyDisplayForward?familyId=98 Introduction to 3C. 3-Ketosteroid receptors

https://www.guidetopharmacology.org/GRAC/FamilyIntroductionForward?familyId=98

Receptors

Androgen receptor

https://www.guidetopharmacology.org/GRAC/ObjectDisplayForward?objectId=628

Glucocorticoid receptor

https://www.guidetopharmacology.org/GRAC/ObjectDisplayForward?objectId=625

Mineralocorticoid receptor

https://www.guidetopharmacology.org/GRAC/ObjectDisplayForward?objectId=626

Progesterone receptor

https://www.guidetopharmacology.org/GRAC/ObjectDisplayForward?objectId=627 


\section{References}

1. Ahrens-Fath I, Politz O, Geserick C and Haendler B. (2005) Androgen receptor function is modulated by the tissue-specific AR45 variant. FEBS J 272: 74-84 [PMID:15634333]

2. Akita K, Harada K, Ichihara J, Takata N, Takahashi Y and Saito K. (2013) A novel selective androgen receptor modulator, NEP28, is efficacious in muscle and brain without serious side effects on prostate. Eur J Pharmacol 720: 107-14 [PMID:24177288]

3. Alexander SPH, Cidlowski JA, Kelly E, Mathie A, Peters JA, Veale EL, Armstrong JF, Faccenda E, Harding SD and Pawson AJ et al.. (2019) THE CONCISE GUIDE TO PHARMACOLOGY 2019/20: Nuclear hormone receptors. Br J Pharmacol 176 Suppl 1: S229-S246 [PMID:31710718]

4. Amasheh S, Epple HJ, Mankertz J, Detjen K, Goltz M, Schulzke JD and Fromm M. (2000) Differential regulation of ENaC by aldosterone in rat early and late distal colon. Ann N Y Acad Sci 915: 92-4 [PMID:11193605]

5. Antonarakis ES, Lu C, Wang H, Luber B, Nakazawa M, Roeser JC, Chen Y, Mohammad TA, Chen $\mathrm{Y}$ and Fedor HL et al.. (2014) AR-V7 and resistance to enzalutamide and abiraterone in prostate cancer. N Engl J Med 371: 1028-38 [PMID:25184630]

6. Anzick SL, Kononen J, Walker RL, Azorsa DO, Tanner MM, Guan XY, Sauter G, Kallioniemi OP, Trent JM and Meltzer PS. (1997) AIB1, a steroid receptor coactivator amplified in breast and ovarian cancer. Science 277: 965-8 [PMID:9252329]

7. Arriza JL, Weinberger C, Cerelli G, Glaser TM, Handelin BL, Housman DE and Evans RM. (1987) Cloning of human mineralocorticoid receptor complementary DNA: structural and functional kinship with the glucocorticoid receptor. Science 237: 268-75 [PMID:3037703]

8. Attia GR, Zeitoun K, Edwards D, Johns A, Carr BR and Bulun SE. (2000) Progesterone receptor isoform A but not B is expressed in endometriosis. J Clin Endocrinol Metab 85: 2897-902 [PMID:10946900]

9. Auerbach SS. DrugMatrix in vitro pharmacology data

10. Auerbach SS and DrugMatrix ${ }^{\circledR}$ and ToxFX ${ }^{\circledR}$ Coordinator National Toxicology Program.. National Toxicology Program: Dept of Health and Human Services.

11. Aupperlee MD, Smith KT, Kariagina A and Haslam SZ. (2005) Progesterone receptor isoforms A and $\mathrm{B}$ : temporal and spatial differences in expression during murine mammary gland development. Endocrinology 146: 3577-88 [PMID:15878961]

12. Bamberger AM, Milde-Langosch K, Schulte HM and Löning T. (2000) Progesterone receptor isoforms, PR-B and PR-A, in breast cancer: correlations with clinicopathologic tumor parameters and expression of AP-1 factors. Horm Res 54: 32-7 [PMID:11182633]

13. Barik J, Marti F, Morel C, Fernandez SP, Lanteri C, Godeheu G, Tassin JP, Mombereau C, Faure P and Tronche F. (2013) Chronic stress triggers social aversion via glucocorticoid receptor in dopaminoceptive neurons. Science 339: 332-5 [PMID:23329050]

14. Barnes PJ, Greening AP and Crompton GK. (1995) Glucocorticoid resistance in asthma. Am J Respir Crit Care Med 152: S125-40 [PMID:7489120]

15. Beggah AT, Escoubet B, Puttini S, Cailmail S, Delage V, Ouvrard-Pascaud A, Bocchi B, Peuchmaur M, Delcayre C, Farman N and Jaisser F. (2002) Reversible cardiac fibrosis and heart failure induced by conditional expression of an antisense mRNA of the mineralocorticoid receptor in cardiomyocytes. Proc Natl Acad Sci USA 99: 7160-5 [PMID:11997477]

16. Bell MG, Gernert DL, Grese TA, Belvo MD, Borromeo PS, Kelley SA, Kennedy JH, Kolis SP, Lander PA and Richey R et al.. (2007) (S)-N-\{3-[1-cyclopropyl-1-(2,4-difluoro-phenyl)-ethyl]-1Hindol-7-yl\}-methanesulfonamide: a potent, nonsteroidal, functional antagonist of the mineralocorticoid receptor. J Med Chem 50: 6443-5 [PMID:18038968]

17. Belvisi MG, Bundschuh DS, Stoeck M, Wicks S, Underwood S, Battram CH, Haddad el-B, Webber SE and Foster ML. (2005) Preclinical profile of ciclesonide, a novel corticosteroid for the treatment of asthma. J Pharmacol Exp Ther 314: 568-74 [PMID:15878996]

18. Bentvelsen FM, McPhaul MJ, Wilson CM, Wilson JD and George FW. (1996) Regulation of immunoreactive androgen receptor in the adrenal gland of the adult rat. Endocrinology 137: 2659-63 [PMID:8770883]

19. Berger M, Rehwinkel H, Dahmen J, Eriksson A, Hansson T, Hossain N, Klingstedt PT, Lepisto M, Nilsson S and Memmerling M et al.. (2014) Phenyl and benzodioxinyl substituted indazoles derivatives Patent number: US8916600.

20. Berger S, Bleich M, Schmid W, Cole TJ, Peters J, Watanabe H, Kriz W, Warth R, Greger R and Schütz G. (1998) Mineralocorticoid receptor knockout mice: pathophysiology of $\mathrm{Na}+$ metabolism. Proc Natl Acad Sci USA 95: 9424-9 [PMID:9689096]

21. Berger S, Wolfer DP, Selbach O, Alter H, Erdmann G, Reichardt HM, Chepkova AN, Welzl H, Haas HL and Lipp HP et al.. (2006) Loss of the limbic mineralocorticoid receptor impairs behavioral plasticity. Proc Natl Acad Sci U S A 103: 195-200 [PMID:16368758]

22. Bergink EW, van Meel F, Turpijn EW and van der Vies J. (1983) Binding of progestagens to receptor proteins in MCF-7 cells. J Steroid Biochem 19: 1563-70 [PMID:6645495]

23. Bhargava A, Fullerton MJ, Myles K, Purdy TM, Funder JW, Pearce D and Cole TJ. (2001) The 
serum- and glucocorticoid-induced kinase is a physiological mediator of aldosterone action. Endocrinology 142: 1587-94 [PMID:11250940]

24. Bigas J, Sevilla LM and Pérez P. (2020) Epidermal Mineralocorticoid Receptor Inactivation Affects the Homeostasis of All Skin Layers in Chronologically Aged Mice. J Invest Dermatol 140: 1899-1908 [PMID:32199993]

25. Biggadike K, Angell RM, Burgess CM, Farrell RM, Hancock AP, Harker AJ, Irving WR, Ioannou C, Procopiou PA and Shaw RE et al.. (2000) Selective plasma hydrolysis of glucocorticoid gamma-lactones and cyclic carbonates by the enzyme paraoxonase: an ideal plasma inactivation mechanism. J Med Chem 43: 19-21 [PMID:10633034]

26. Bledsoe RK, Madauss KP, Holt JA, Apolito CJ, Lambert MH, Pearce KH, Stanley TB, Stewart EL, Trump RP, Willson TM and Williams SP. (2005) A ligand-mediated hydrogen bond network required for the activation of the mineralocorticoid receptor. J Biol Chem 280: 31283-93 [PMID:15967794]

27. Bloem LJ, Guo C and Pratt JH. (1995) Identification of a splice variant of the rat and human mineralocorticoid receptor genes. J Steroid Biochem Mol Biol 55: 159-62 [PMID:7495694]

28. Boonyaratanakornkit V, McGowan E, Sherman L, Mancini MA, Cheskis BJ and Edwards DP. (2007) The role of extranuclear signaling actions of progesterone receptor in mediating progesterone regulation of gene expression and the cell cycle. Mol Endocrinol 21: 359-75 [PMID:17138644]

29. Boonyaratanakornkit V, Melvin V, Prendergast P, Altmann M, Ronfani L, Bianchi ME, Taraseviciene L, Nordeen SK, Allegretto EA and Edwards DP. (1998) High-mobility group chromatin proteins 1 and 2 functionally interact with steroid hormone receptors to enhance their DNA binding in vitro and transcriptional activity in mammalian cells. Mol Cell Biol 18: 4471-87 [PMID:9671457]

30. Boonyaratanakornkit V, Scott MP, Ribon V, Sherman L, Anderson SM, Maller JL, Miller WT and Edwards DP. (2001) Progesterone receptor contains a proline-rich motif that directly interacts with SH3 domains and activates c-Src family tyrosine kinases. Mol Cell 8: 269-80 [PMID:11545730]

31. Boulkroun S, Fay M, Zennaro MC, Escoubet B, Jaisser F, Blot-Chabaud M, Farman N and Courtois-Coutry N. (2002) Characterization of rat NDRG2 (N-Myc downstream regulated gene 2), a novel early mineralocorticoid-specific induced gene. J Biol Chem 277: 31506-15 [PMID:12072429]

32. Boyle MP, Brewer JA, Funatsu M, Wozniak DF, Tsien JZ, Izumi Y and Muglia LJ. (2005) Acquired deficit of forebrain glucocorticoid receptor produces depression-like changes in adrenal axis regulation and behavior. Proc Natl Acad Sci USA 102: 473-8 [PMID:15623560]

33. Bray PJ and Cotton RG. (2003) Variations of the human glucocorticoid receptor gene (NR3C1): pathological and in vitro mutations and polymorphisms. Hum Mutat 21: 557-68 [PMID:12754700]

34. Brennan FE and Fuller PJ. (2000) Rapid upregulation of serum and glucocorticoid-regulated kinase (sgk) gene expression by corticosteroids in vivo. Mol Cell Endocrinol 166: 129-36 [PMID:10996431]

35. Brennan FE and Fuller PJ. (1999) Acute regulation by corticosteroids of channel-inducing factor gene messenger ribonucleic acid in the distal colon. Endocrinology 140: 1213-8 [PMID:10067846]

36. Brennan FE and Fuller PJ. (2006) Mammalian K-ras2 is a corticosteroid-induced gene in vivo. Endocrinology 147: 2809-16 [PMID:16543373]

37. Brewer JA, Khor B, Vogt SK, Muglia LM, Fujiwara H, Haegele KE, Sleckman BP and Muglia LJ. (2003) T-cell glucocorticoid receptor is required to suppress COX-2-mediated lethal immune activation. Nat Med 9: 1318-22 [PMID:12949501]

38. Brown CJ, Goss SJ, Lubahn DB, Joseph DR, Wilson EM, French FS and Willard HF. (1989) Androgen receptor locus on the human X chromosome: regional localization to Xq11-12 and description of a DNA polymorphism. Am J Hum Genet 44: 264-9 [PMID:2563196]

39. Bruner KL, Derfoul A, Robertson NM, Guerriero G, Fernandes-Alnemri T, Alnemri ES and Litwack G. (1997) The unliganded mineralocorticoid receptor is associated with heat shock proteins 70 and 90 and the immunophilin FKBP-52. Recept Signal Transduct 7: 85-98 [PMID:9392437]

40. Brönnegård M, Stierna P and Marcus C. (1996) Glucocorticoid resistant syndromes--molecular basis and clinical presentations. J Neuroendocrinol 8: 405-15 [PMID:8809670]

41. Buneman P, Christie G, Davies JA, Dimitrellou R, Harding SD, Pawson AJ, Sharman JL and Wu Y. (2020) Why data citation isn't working, and what to do about it Database 2020 [PMID:32367113]

42. Burd CJ, Petre CE, Morey LM, Wang Y, Revelo MP, Haiman CA, Lu S, Fenoglio-Preiser CM, Li J and Knudsen ES et al.. (2006) Cyclin D1b variant influences prostate cancer growth through aberrant androgen receptor regulation. Proc Natl Acad Sci USA 103: 2190-5 [PMID:16461912]

43. Bärfacker L, Kuhl A, Hillisch A, Grosser R, Figueroa-Pérez S, Heckroth H, Nitsche A, Ergüden 
JK, Gielen-Haertwig H and Schlemmer KH et al.. (2012) Discovery of BAY 94-8862: a nonsteroidal antagonist of the mineralocorticoid receptor for the treatment of cardiorenal diseases. ChemMedChem 7: 1385-403 [PMID:22791416]

44. Cain DW and Cidlowski JA. (2017) Immune regulation by glucocorticoids. Nat Rev Immunol 17: 233-247 [PMID:28192415]

45. Caldenhoven E, Liden J, Wissink S, Van de Stolpe A, Raaijmakers J, Koenderman L, Okret S, Gustafsson JA and Van der Saag PT. (1995) Negative cross-talk between RelA and the glucocorticoid receptor: a possible mechanism for the antiinflammatory action of glucocorticoids. Mol Endocrinol 9: 401-12 [PMID:7659084]

46. Canonica J, Sergi C, Maillard M, Klusonova P, Odermatt A, Koesters R, Loffing-Cueni D, Loffing J, Rossier B and Frateschi S et al.. (2016) Adult nephron-specific MR-deficient mice develop a severe renal PHA-1 phenotype. Pflugers Arch 468: 895-908 [PMID:26762397]

47. Caprio M, Newfell BG, la Sala A, Baur W, Fabbri A, Rosano G, Mendelsohn ME and Jaffe IZ. (2008) Functional mineralocorticoid receptors in human vascular endothelial cells regulate intercellular adhesion molecule-1 expression and promote leukocyte adhesion. Circ Res 102: 1359-67 [PMID:18467630]

48. Casimiro-Garcia A, Piotrowski DW, Ambler C, Arhancet GB, Banker ME, Banks T, Boustany-Kari CM, Cai C, Chen X and Eudy R et al.. (2014) Identification of (R)-6-(1-(4-cyano-3methylphenyl)-5-cyclopentyl-4,5-dihydro-1 H-pyrazol-3-yl)-2-methoxynicotinic acid, a highly potent and selective nonsteroidal mineralocorticoid receptor antagonist. J Med Chem 57: 427388 [PMID:24738581]

49. Cassuto H, Kochan K, Chakravarty K, Cohen H, Blum B, Olswang Y, Hakimi P, Xu C, Massillon D, Hanson RW and Reshef L. (2005) Glucocorticoids regulate transcription of the gene for phosphoenolpyruvate carboxykinase in the liver via an extended glucocorticoid regulatory unit. $J$ Biol Chem 280: 33873-84 [PMID:16100117]

50. Chamness GC, Asch RH and Pauerstein CJ. (1980) Danazol binding and translocation of steroid receptors. Am J Obstet Gynecol 136: 426-9 [PMID:7355922]

51. Chan KK, Tsui SK, Ngai SM, Lee SM, Kotaka M, Waye MM, Lee CY and Fung KP. (2000) Proteinprotein interaction of FHL2, a LIM domain protein preferentially expressed in human heart, with hCDC47. J Cell Biochem 76: 499-508 [PMID:10649446]

52. Chan SW and Hong W. (2001) Retinoblastoma-binding protein 2 (Rbp2) potentiates nuclear hormone receptor-mediated transcription. J Biol Chem 276: 28402-12 [PMID:11358960]

53. Chang C, Chen YT, Yeh SD, Xu Q, Wang RS, Guillou F, Lardy H and Yeh S. (2004) Infertility with defective spermatogenesis and hypotestosteronemia in male mice lacking the androgen receptor in Sertoli cells. Proc Natl Acad Sci USA 101: 6876-81 [PMID:15107499]

54. Chen H, Lin RJ, Schiltz RL, Chakravarti D, Nash A, Nagy L, Privalsky ML, Nakatani Y and Evans RM. (1997) Nuclear receptor coactivator ACTR is a novel histone acetyltransferase and forms a multimeric activation complex with P/CAF and CBP/p300. Cell 90: 569-80 [PMID:9267036]

55. Cheng S, Brzostek S, Lee SR, Hollenberg AN and Balk SP. (2002) Inhibition of the dihydrotestosterone-activated androgen receptor by nuclear receptor corepressor. $\mathrm{Mol}$ Endocrinol 16: 1492-501 [PMID:12089345]

56. Choong CS, Sturm MJ, Strophair JA, McCulloch RK and Hurley DM. (1997) Reduced expression and normal nucleotide sequence of androgen receptor gene coding and promoter regions in a family with partial androgen insensitivity syndrome. Clin Endocrinol (Oxf) 46: 281-8 [PMID:9156036]

57. Chwalisz K, DeManno D, Garg R, Larsen L, Mattia-Goldberg C and Stickler T. (2004) Therapeutic potential for the selective progesterone receptor modulator asoprisnil in the treatment of leiomyomata. Semin Reprod Med 22: 113-9 [PMID:15164306]

58. Cidlowski JA, Bellingham DL, Powell-Oliver FE, Lubahn DB and Sar M. (1990) Novel antipeptide antibodies to the human glucocorticoid receptor: recognition of multiple receptor forms in vitro and distinct localization of cytoplasmic and nuclear receptors. Mol Endocrinol 4: 1427-37 [PMID:1704480]

59. Cidlowski JA and Munck A. (1976) Concanavalin A-induced glucocorticoid resistance in rat thymus cells: decreased cytoplasmic and nuclear receptor binding of dexamethasone. J Steroid Biochem 7: 1141-5 [PMID:1025360]

60. Clark RD, Ray NC, Williams K, Blaney P, Ward S, Crackett PH, Hurley C, Dyke HJ, Clark DE and Lockey P et al.. (2008) 1H-Pyrazolo[3,4-g]hexahydro-isoquinolines as selective glucocorticoid receptor antagonists with high functional activity. Bioorg Med Chem Lett 18: 1312-7 [PMID:18226897]

61. Cleutjens KB, van Eekelen CC, van der Korput HA, Brinkmann AO and Trapman J. (1996) Two androgen response regions cooperate in steroid hormone regulated activity of the prostatespecific antigen promoter. J Biol Chem 271: 6379-88 [PMID:8626436]

62. Coghlan MJ, Kym PR, Elmore SW, Wang AX, Luly JR, Wilcox D, Stashko M, Lin CW, Miner J and Tyree C et al.. (2001) Synthesis and characterization of non-steroidal ligands for the glucocorticoid receptor: selective quinoline derivatives with prednisolone-equivalent functional 
activity. J Med Chem 44: 2879-85 [PMID:11520196]

63. Cole TJ, Blendy JA, Monaghan AP, Krieglstein K, Schmid W, Aguzzi A, Fantuzzi G, Hummler E, Unsicker K and Schütz G. (1995) Targeted disruption of the glucocorticoid receptor gene blocks adrenergic chromaffin cell development and severely retards lung maturation. Genes Dev 9: 1608-21 [PMID:7628695]

64. Cole TJ, Myles K, Purton JF, Brereton PS, Solomon NM, Godfrey DI and Funder JW. (2001) GRKO mice express an aberrant dexamethasone-binding glucocorticoid receptor, but are profoundly glucocorticoid resistant. Mol Cell Endocrinol 173: 193-202 [PMID:11223190]

65. Cole TJ, Terella L, Morgan J, Alexiadis M, Yao YZ, Enriori P, Young MJ and Fuller PJ. (2015) Aldosterone-Mediated Renal Sodium Transport Requires Intact Mineralocorticoid Receptor DNA-Binding in the Mouse. Endocrinology 156: 2958-68 [PMID:26066075]

66. Cole TJ and Young MJ. (2017) 30 YEARS OF THE MINERALOCORTICOID RECEPTOR: Mineralocorticoid receptor null mice: informing cell-type-specific roles. J Endocrinol 234: T83T92 [PMID:28550025]

67. Collin M, Niemann F and Jaisser F. (2014) Mineralocorticoid receptor modulators: a patent review (2007 - 2012). Expert Opin Ther Pat 24: 177-83 [PMID:24215301]

68. Conway-Campbell BL, Sarabdjitsingh RA, McKenna MA, Pooley JR, Kershaw YM, Meijer OC, De Kloet ER and Lightman SL. (2010) Glucocorticoid ultradian rhythmicity directs cyclical gene pulsing of the clock gene period 1 in rat hippocampus. J Neuroendocrinol 22: 1093-100 [PMID:20649850]

69. Corrigan CJ, Brown PH, Barnes NC, Szefler SJ, Tsai JJ, Frew AJ and Kay AB. (1991) Glucocorticoid resistance in chronic asthma. Glucocorticoid pharmacokinetics, glucocorticoid receptor characteristics, and inhibition of peripheral blood T cell proliferation by glucocorticoids in vitro. Am Rev Respir Dis 144: 1016-25 [PMID:1952426]

70. Coulthard VH, Matsuda S and Heery DM. (2003) An extended LXXLL motif sequence determines the nuclear receptor binding specificity of TRAP220. J Biol Chem 278: 10942-51 [PMID:12556447]

71. Cruz-Topete D and Cidlowski JA. (2015) One hormone, two actions: anti- and pro-inflammatory effects of glucocorticoids. Neuroimmunomodulation 22: 20-32 [PMID:25227506]

72. Cukier HN, Griswold AJ, Hofmann NK, Gomez L, Whitehead PL, Abramson RK, Gilbert JR, Cuccaro ML, Dykxhoorn DM and Pericak-Vance MA. (2020) Three Brothers With Autism Carry a Stop-Gain Mutation in the HPA-Axis Gene NR3C2. Autism Res 13: 523-531 [PMID:32064789]

73. D'Adamio F, Zollo O, Moraca R, Ayroldi E, Bruscoli S, Bartoli A, Cannarile L, Migliorati G and Riccardi C. (1997) A new dexamethasone-induced gene of the leucine zipper family protects $T$ lymphocytes from TCR/CD3-activated cell death. Immunity 7: 803-12 [PMID:9430225]

74. Dahlman-Wright K, Cavailles V, Fuqua SA, Jordan VC, Katzenellenbogen JA, Korach KS, Maggi A, Muramatsu M, Parker MG and Gustafsson JA. (2006) International Union of Pharmacology. LXIV. Estrogen receptors. Pharmacol Rev 58: 773-81 [PMID:17132854]

75. Daniel AR, Faivre EJ and Lange CA. (2007) Phosphorylation-dependent antagonism of sumoylation derepresses progesterone receptor action in breast cancer cells. Mol Endocrinol 21: 2890-906 [PMID:17717077]

76. Danielsen M, Northrop JP and Ringold GM. (1986) The mouse glucocorticoid receptor: mapping of functional domains by cloning, sequencing and expression of wild-type and mutant receptor proteins. EMBO J 5: 2513-22 [PMID:3780669]

77. De Bosscher K, Vanden Berghe W, Beck IM, Van Molle W, Hennuyer N, Hapgood J, Libert C, Staels B, Louw A and Haegeman G. (2005) A fully dissociated compound of plant origin for inflammatory gene repression. Proc Natl Acad Sci U S A 102: 15827-32 [PMID:16243974]

78. de Kloet ER, Van Acker SA, Sibug RM, Oitzl MS, Meijer OC, Rahmouni K and de Jong W. (2000) Brain mineralocorticoid receptors and centrally regulated functions. Kidney Int 57: 1329-36 [PMID:10760063]

79. De Rubeis S, He X, Goldberg AP, Poultney CS, Samocha K, Cicek AE, Kou Y, Liu L, Fromer M and Walker S et al.. (2014) Synaptic, transcriptional and chromatin genes disrupted in autism. Nature 515: 209-15 [PMID:25363760]

80. De Vivo I, Huggins GS, Hankinson SE, Lescault PJ, Boezen M, Colditz GA and Hunter DJ. (2002) A functional polymorphism in the promoter of the progesterone receptor gene associated with endometrial cancer risk. Proc Natl Acad Sci USA 99: 12263-8 [PMID:12218173]

81. DeRijk RH, Wüst S, Meijer OC, Zennaro MC, Federenko IS, Hellhammer DH, Giacchetti G, Vreugdenhil E, Zitman FG and de Kloet ER. (2006) A common polymorphism in the mineralocorticoid receptor modulates stress responsiveness. J Clin Endocrinol Metab 91: 5083-9 [PMID:17018659]

82. Dietz JD, Du S, Bolten CW, Payne MA, Xia C, Blinn JR, Funder JW and Hu X. (2008) A number of marketed dihydropyridine calcium channel blockers have mineralocorticoid receptor antagonist activity. Hypertension 51: 742-8 [PMID:18250364]

83. Dobson MG, Redfern CP, Unwin N and Weaver JU. (2001) The N363S polymorphism of the glucocorticoid receptor: potential contribution to central obesity in men and lack of association 
with other risk factors for coronary heart disease and diabetes mellitus. J Clin Endocrinol Metab 86: 2270-4 [PMID:11344238]

84. Edelman JL and Nehme A. (2013) PHARMACEUTICAL COMPOSITIONS AND METHODS OF USE OF 4-PREGENEN-11ß-17-21-TRIOL-3,20-DIONE DERIVATIVES Patent number: WO2013071010.

85. Edwards JP, West SJ, Marschke KB, Mais DE, Gottardis MM and Jones TK. (1998) 5-Aryl-1,2dihydro-5H-chromeno[3,4-f]quinolines as potent, orally active, nonsteroidal progesterone receptor agonists: the effect of D-ring substituents. J Med Chem 41: 303-10 [PMID:9464361]

86. Edwards JP, Zhi L, Pooley CL, Tegley CM, West SJ, Wang MW, Gottardis MM, Pathirana C, Schrader WT and Jones TK. (1998) Preparation, resolution, and biological evaluation of 5-aryl-1, 2-dihydro-5H-chromeno[3,4-f]quinolines: potent, orally active, nonsteroidal progesterone receptor agonists. J Med Chem 41: 2779-85 [PMID:9667968]

87. Efstathiou E, Titus M, Wen S, Hoang A, Karlou M, Ashe R, Tu SM, Aparicio A, Troncoso P and Mohler J et al. (2015) Molecular characterization of enzalutamide-treated bone metastatic castration-resistant prostate cancer. Eur Urol 67: 53-60 [PMID:24882673]

88. Elbi C, Walker DA, Romero G, Sullivan WP, Toft DO, Hager GL and DeFranco DB. (2004) Molecular chaperones function as steroid receptor nuclear mobility factors. Proc Natl Acad Sci USA 101: 2876-81 [PMID:14978266]

89. Encío IJ and Detera-Wadleigh SD. (1991) The genomic structure of the human glucocorticoid receptor. J Biol Chem 266: 7182-8 [PMID:1707881]

90. Escoubet B, Couffignal C, Laisy JP, Mangin L, Chillon S, Laouénan C, Serfaty JM, Jeunemaitre X, Mentré F and Zennaro MC. (2013) Cardiovascular effects of aldosterone: insight from adult carriers of mineralocorticoid receptor mutations. Circ Cardiovasc Genet 6: 381-90 [PMID:23852419]

91. Fakitsas P, Adam G, Daidié D, van Bemmelen MX, Fouladkou F, Patrignani A, Wagner U, Warth R, Camargo SM and Staub O et al.. (2007) Early aldosterone-induced gene product regulates the epithelial sodium channel by deubiquitylation. J Am Soc Nephrol 18: 1084-92 [PMID:17344426]

92. Fan W, Yanase T, Nomura M, Okabe T, Goto K, Sato T, Kawano H, Kato S and Nawata H. (2005) Androgen receptor null male mice develop late-onset obesity caused by decreased energy expenditure and lipolytic activity but show normal insulin sensitivity with high adiponectin secretion. Diabetes 54: 1000-8 [PMID:15793238]

93. Fang H, Tong W, Branham WS, Moland CL, Dial SL, Hong H, Xie Q, Perkins R, Owens W and Sheehan DM. (2003) Study of 202 natural, synthetic, and environmental chemicals for binding to the androgen receptor. Chem Res Toxicol 16: 1338-58 [PMID:14565775]

94. Faresse N, Ruffieux-Daidie D, Salamin M, Gomez-Sanchez CE and Staub O. (2010) Mineralocorticoid receptor degradation is promoted by Hsp90 inhibition and the ubiquitinprotein ligase CHIP. Am J Physiol Renal Physiol 299: F1462-72 [PMID:20861078]

95. Fensome A, Adams WR, Adams AL, Berrodin TJ, Cohen J, Huselton C, Illenberger A, Kern JC, Hudak VA and Marella MA et al.. (2008) Design, synthesis, and SAR of new pyrrole-oxindole progesterone receptor modulators leading to 5-(7-fluoro-3,3-dimethyl-2-oxo-2,3-dihydro-1Hindol-5-yl)-1-methyl-1H-pyrrole-2-carbonitrile (WAY-255348). J Med Chem 51: 1861-73 [PMID:18318463]

96. Ferraboschi P, Legnani L, Celasco G, Moro L, Ragonesi L and Colombo D. (2014) A full conformational characterization of antiandrogen cortexolone-17-propionate and related compounds through theoretical calculations and nuclear magnetic resonance spectroscopy MedChemComm 5: 904-914

97. Finn CA and Pope M. (1984) Vascular and cellular changes in the decidualized endometrium of the ovariectomized mouse following cessation of hormone treatment: a possible model for menstruation. J Endocrinol 100: 295-300 [PMID:6699534]

98. Fraccarollo D, Berger S, Galuppo P, Kneitz S, Hein L, Schütz G, Frantz S, Ertl G and Bauersachs J. (2011) Deletion of cardiomyocyte mineralocorticoid receptor ameliorates adverse remodeling after myocardial infarction. Circulation 123: 400-8 [PMID:21242479]

99. Francke U and Taggart RT. (1980) Comparative gene mapping: order of loci on the $\mathrm{X}$ chromosome is different in mice and humans. Proc Natl Acad Sci USA 77: 3595-9 [PMID:6251472]

100. Fu M, Wang C, Reutens AT, Wang J, Angeletti RH, Siconolfi-Baez L, Ogryzko V, Avantaggiati ML and Pestell RG. (2000) p300 and p300/cAMP-response element-binding protein-associated factor acetylate the androgen receptor at sites governing hormone-dependent transactivation. J Biol Chem 275: 20853-60 [PMID:10779504]

101. Fujimoto N, Yeh S, Kang HY, Inui S, Chang HC, Mizokami A and Chang C. (1999) Cloning and characterization of androgen receptor coactivator, ARA55, in human prostate. J Biol Chem 274: 8316-21 [PMID:10075738]

102. Fuller PJ, Yao YZ, Jin R, He S, Martín-Fernández B, Young MJ and Smith BJ. (2019) Molecular evolution of the switch for progesterone and spironolactone from mineralocorticoid receptor agonist to antagonist. Proc Natl Acad Sci U S A 116: 18578-18583 [PMID:31439819]

103. Fuse H, Kitagawa H and Kato S. (2000) Characterization of transactivational property and 
coactivator mediation of rat mineralocorticoid receptor activation function-1 (AF-1). Mol

Endocrinol 14: 889-99 [PMID:10847590]

104. Galigniana MD, Echeverría PC, Erlejman AG and Piwien-Pilipuk G. (2010) Role of molecular chaperones and TPR-domain proteins in the cytoplasmic transport of steroid receptors and their passage through the nuclear pore. Nucleus 1: 299-308 [PMID:21113270]

105. Galigniana MD, Erlejman AG, Monte M, Gomez-Sanchez C and Piwien-Pilipuk G. (2010) The hsp90-FKBP52 complex links the mineralocorticoid receptor to motor proteins and persists bound to the receptor in early nuclear events. Mol Cell Biol 30: 1285-98 [PMID:20038533]

106. Gallo LI, Ghini AA, Piwien Pilipuk G and Galigniana MD. (2007) Differential recruitment of tetratricorpeptide repeat domain immunophilins to the mineralocorticoid receptor influences both heat-shock protein 90-dependent retrotransport and hormone-dependent transcriptional activity. Biochemistry 46: 14044-57 [PMID:18001136]

107. Gasparini S, Resch JM, Narayan SV, Peltekian L, Iverson GN, Karthik S and Geerling JC. (2019) Aldosterone-sensitive HSD2 neurons in mice. Brain Struct Funct 224: 387-417 [PMID:30343334]

108. Gass EK, Leonhardt SA, Nordeen SK and Edwards DP. (1998) The antagonists RU486 and ZK98299 stimulate progesterone receptor binding to deoxyribonucleic acid in vitro and in vivo, but have distinct effects on receptor conformation. Endocrinology 139: 1905-19 [PMID:9528977]

109. Gaughan L, Logan IR, Cook S, Neal DE and Robson CN. (2002) Tip60 and histone deacetylase 1 regulate androgen receptor activity through changes to the acetylation status of the receptor. $J$ Biol Chem 277: 25904-13 [PMID:11994312]

110. Ge RS, Dong Q, Sottas CM, Latif SA, Morris DJ and Hardy MP. (2005) Stimulation of testosterone production in rat Leydig cells by aldosterone is mineralocorticoid receptor mediated. Mol Cell Endocrinol 243: 35-42 [PMID:16188378]

111. Georget V, Térouanne B, Nicolas JC and Sultan C. (2002) Mechanism of antiandrogen action: key role of hsp90 in conformational change and transcriptional activity of the androgen receptor. Biochemistry 41: 11824-31 [PMID:12269826]

112. Germain P, Staels B, Dacquet C, Spedding M and Laudet V. (2006) Overview of nomenclature of nuclear receptors. Pharmacol Rev 58: 685-704 [PMID:17132848]

113. Geserick C, Meyer HA, Barbulescu K and Haendler B. (2003) Differential modulation of androgen receptor action by deoxyribonucleic acid response elements. Mol Endocrinol 17: 1738-50 [PMID:12791770]

114. Ghidini E, Marchini G, Capelli AM, Carnini C, Cenacchi V, Fioni A, Facchinetti F and Rancati F. (2018) Novel Pyrrolidine Derivatives of Budesonide as Long Acting Inhaled Corticosteroids for the Treatment of Pulmonary Inflammatory Diseases. J Med Chem 61: 4757-4773 [PMID:29741897]

115. Giangrande PH, Kimbrel EA, Edwards DP and McDonnell DP. (2000) The opposing transcriptional activities of the two isoforms of the human progesterone receptor are due to differential cofactor binding. Mol Cell Biol 20: 3102-15 [PMID:10757795]

116. Giangrande PH, Pollio G and McDonnell DP. (1997) Mapping and characterization of the functional domains responsible for the differential activity of the A and B isoforms of the human progesterone receptor. J Biol Chem 272: 32889-900 [PMID:9407067]

117. Giannopoulos G and Keichline D. (1981) Species-related differences in steroid-binding specificity of glucocorticoid receptors in lung. Endocrinology 108: 1414-9 [PMID:7472274]

118. Giwercman A, Kledal T, Schwartz M, Giwercman YL, Leffers H, Zazzi H, Wedell A and Skakkebaek NE. (2000) Preserved male fertility despite decreased androgen sensitivity caused by a mutation in the ligand-binding domain of the androgen receptor gene. J Clin Endocrinol Metab 85: 2253-9 [PMID:10852459]

119. Goswami D, Callaway C, Pascal BD, Kumar R, Edwards DP and Griffin PR. (2014) Influence of domain interactions on conformational mobility of the progesterone receptor detected by hydrogen/deuterium exchange mass spectrometry. Structure 22: 961-73 [PMID:24909783]

120. Granberg KL, Yuan ZQ, Lindmark B, Edman K, Kajanus J, Hogner A, Malmgren M, O'Mahony G, Nordqvist A and Lindberg J et al.. (2019) Identification of Mineralocorticoid Receptor Modulators with Low Impact on Electrolyte Homeostasis but Maintained Organ Protection. $J$ Med Chem 62: 1385-1406 [PMID:30596500]

121. Grimm SL, Ward RD, Obr AE, Franco HL, Fernandez-Valdivia R, Kim JS, Roberts JM, Jeong JW, DeMayo FJ and Lydon JP et al.. (2014) A role for site-specific phosphorylation of mouse progesterone receptor at serine 191 in vivo. Mol Endocrinol 28: 2025-37 [PMID:25333515]

122. Grossmann C and Gekle M. (2012) Interaction between mineralocorticoid receptor and epidermal growth factor receptor signaling. Mol Cell Endocrinol 350: 235-41 [PMID:21827828]

123. Guerrero J, Alfaro IE, Gómez F, Protter AA and Bernales S. (2013) Enzalutamide, an androgen receptor signaling inhibitor, induces tumor regression in a mouse model of castration-resistant prostate cancer. Prostate 73: 1291-305 [PMID:23765603]

124. Gumz ML, Popp MP, Wingo CS and Cain BD. (2003) Early transcriptional effects of aldosterone 
in a mouse inner medullary collecting duct cell line. Am J Physiol Renal Physiol 285: F664-73 [PMID:12770840]

125. Guo C, Linton A, Kephart S, Ornelas M, Pairish M, Gonzalez J, Greasley S, Nagata A, Burke BJ and Edwards $\mathrm{M}$ et al.. (2011) Discovery of aryloxy tetramethylcyclobutanes as novel androgen receptor antagonists. J Med Chem 54: 7693-704 [PMID:21936524]

126. Guo Z, Yang X, Sun F, Jiang R, Linn DE, Chen H, Chen H, Kong X, Melamed J and Tepper CG et al.. (2009) A novel androgen receptor splice variant is up-regulated during prostate cancer progression and promotes androgen depletion-resistant growth. Cancer Res 69: 2305-13 [PMID:19244107]

127. Haarman EG, Kaspers GJ, Pieters R, Rottier MM and Veerman AJ. (2004) Glucocorticoid receptor alpha, beta and gamma expression vs in vitro glucocorticod resistance in childhood leukemia. Leukemia 18: 530-7 [PMID:14724649]

128. Haelens A, Verrijdt G, Callewaert L, Peeters B, Rombauts W and Claessens F. (2001) Androgenreceptor-specific DNA binding to an element in the first exon of the human secretory component gene. Biochem J 353: 611-20 [PMID:11171058]

129. Hagan CR, Regan TM, Dressing GE and Lange CA. (2011) ck2-dependent phosphorylation of progesterone receptors (PR) on Ser81 regulates PR-B isoform-specific target gene expression in breast cancer cells. Mol Cell Biol 31: 2439-52 [PMID:21518957]

130. Hamann LG, Farmer LJ, Johnson MG, Bender SL, Mais DE, Wang MW, Crombie D, Goldman ME and Jones TK. (1996) Synthesis and biological activity of novel nonsteroidal progesterone receptor antagonists based on cyclocymopol monomethyl ether. J Med Chem 39: 1778-89 [PMID:8627601]

131. Hamann LG, Higuchi RI, Zhi L, Edwards JP, Wang XN, Marschke KB, Kong JW, Farmer LJ and Jones TK. (1998) Synthesis and biological activity of a novel series of nonsteroidal, peripherally selective androgen receptor antagonists derived from 1,2-dihydropyridono[5,6-g]quinolines. $J$ Med Chem 41: 623-39 [PMID:9484511]

132. Han X, Zhao L, Xiang W, Qin C, Miao B, Xu T, Wang M, Yang CY, Chinnaswamy K and Stuckey J et al.. (2019) Discovery of Highly Potent and Efficient PROTAC Degraders of Androgen Receptor (AR) by Employing Weak Binding Affinity VHL E3 Ligase Ligands. J Med Chem 62: 11218-11231 [PMID:31804827]

133. Handratta VD, Vasaitis TS, Njar VC, Gediya LK, Kataria R, Chopra P, Newman Jr D, Farquhar R, Guo Z and Qiu Y et al.. (2005) Novel C-17-heteroaryl steroidal CYP17 inhibitors/antiandrogens: synthesis, in vitro biological activity, pharmacokinetics, and antitumor activity in the LAPC4 human prostate cancer xenograft model. J Med Chem 48: 2972-84 [PMID:15828836]

134. Harcken C, Riether D, Liu P, Razavi H, Patel U, Lee T, Bosanac T, Ward Y, Ralph M and Chen Z et al.. (2014) Optimization of drug-like properties of nonsteroidal glucocorticoid mimetics and identification of a clinical candidate. ACS Med Chem Lett 5: 1318-23 [PMID:25516791]

135. Heier CR, Damsker JM, Yu Q, Dillingham BC, Huynh T, Van der Meulen JH, Sali A, Miller BK, Phadke A and Scheffer L et al.. (2013) VBP15, a novel anti-inflammatory and membranestabilizer, improves muscular dystrophy without side effects. EMBO Mol Med 5: 1569-85 [PMID:24014378]

136. Heikinheimo O, Kontula K, Croxatto H, Spitz I, Luukkainen T and Lähteenmäki P. (1987) Plasma concentrations and receptor binding of RU 486 and its metabolites in humans. J Steroid Biochem 26: 279-84 [PMID:3560943]

137. Hellal-Levy C, Couette B, Fagart J, Souque A, Gomez-Sanchez C and Rafestin-Oblin M. (1999) Specific hydroxylations determine selective corticosteroid recognition by human glucocorticoid and mineralocorticoid receptors. FEBS Lett 464: 9-13 [PMID:10611474]

138. Hemmerling M, Nilsson S, Edman K, Eirefelt S, Russell W, Hendrickx R, Johnsson E, Kärrman Mårdh C, Berger M and Rehwinkel H et al.. (2017) Selective Nonsteroidal Glucocorticoid Receptor Modulators for the Inhaled Treatment of Pulmonary Diseases. J Med Chem 60: 85918605 [PMID:28937774]

139. Henriksson A, Almlöf T, Ford J, McEwan IJ, Gustafsson JA and Wright AP. (1997) Role of the Ada adaptor complex in gene activation by the glucocorticoid receptor. Mol Cell Biol 17: 3065-73 [PMID:9154805]

140. Higuchi RI, Arienti KL, López FJ, Mani NS, Mais DE, Caferro TR, Long YO, Jones TK, Edwards JP and Zhi L et al.. (2007) Novel series of potent, nonsteroidal, selective androgen receptor modulators based on 7H-[1,4] oxazino[3,2-g]quinolin-7-ones. J Med Chem 50: 2486-96 [PMID:17439112]

141. Hollenberg SM, Weinberger C, Ong ES, Cerelli G, Oro A, Lebo R, Thompson EB, Rosenfeld MG and Evans RM. (1985) Primary structure and expression of a functional human glucocorticoid receptor cDNA. Nature 318: 635-41 [PMID:2867473]

142. Hong H, Kohli K, Garabedian MJ and Stallcup MR. (1997) GRIP1, a transcriptional coactivator for the AF-2 transactivation domain of steroid, thyroid, retinoid, and vitamin D receptors. $\mathrm{Mol}$ Cell Biol 17: 2735-44 [PMID:9111344]

143. Hong H, Kohli K, Trivedi A, Johnson DL and Stallcup MR. (1996) GRIP1, a novel mouse protein that serves as a transcriptional coactivator in yeast for the hormone binding domains of steroid 
receptors. Proc Natl Acad Sci USA 93: 4948-52 [PMID:8643509]

144. Hsiao PW, Fryer CJ, Trotter KW, Wang W and Archer TK. (2003) BAF60a mediates critical interactions between nuclear receptors and the BRG1 chromatin-remodeling complex for transactivation. Mol Cell Biol 23: 6210-20 [PMID:12917342]

145. Hsiao PW, Lin DL, Nakao R and Chang C. (1999) The linkage of Kennedy's neuron disease to ARA24, the first identified androgen receptor polyglutamine region-associated coactivator. J Biol Chem 274: 20229-34 [PMID:10400640]

146. Hu R, Dunn TA, Wei S, Isharwal S, Veltri RW, Humphreys E, Han M, Partin AW, Vessella RL and Isaacs WB et al.. (2009) Ligand-independent androgen receptor variants derived from splicing of cryptic exons signify hormone-refractory prostate cancer. Cancer Res 69: 16-22 [PMID:19117982]

147. Hu YC, Yeh S, Yeh SD, Sampson ER, Huang J, Li P, Hsu CL, Ting HJ, Lin HK, Wang L, Kim E, Ni J and Chang C. (2004) Functional domain and motif analyses of androgen receptor coregulator ARA70 and its differential expression in prostate cancer. J Biol Chem 279: 33438-46 [PMID:15166229]

148. Hubler TR and Scammell JG. (2004) Intronic hormone response elements mediate regulation of FKBP5 by progestins and glucocorticoids. Cell Stress Chaperones 9: 243-52 [PMID:15544162]

149. Hudson WH, Youn $C$ and Ortlund EA. (2013) The structural basis of direct glucocorticoidmediated transrepression. Nat Struct Mol Biol 20: 53-8 [PMID:23222642]

150. Hudson WH, Youn C and Ortlund EA. (2014) Crystal structure of the mineralocorticoid receptor DNA binding domain in complex with DNA. PLoS ONE 9: e107000 [PMID:25188500]

151. Huizenga NA, Koper JW, De Lange P, Pols HA, Stolk RP, Burger H, Grobbee DE, Brinkmann AO, De Jong FH and Lamberts SW. (1998) A polymorphism in the glucocorticoid receptor gene may be associated with and increased sensitivity to glucocorticoids in vivo. J Clin Endocrinol Metab 83: 144-51 [PMID:9435432]

152. Hultman ML, Krasnoperova NV, Li S, Du S, Xia C, Dietz JD, Lala DS, Welsch DJ and Hu X. (2005) The ligand-dependent interaction of mineralocorticoid receptor with coactivator and corepressor peptides suggests multiple activation mechanisms. Mol Endocrinol 19: 1460-73 [PMID:15761029]

153. Hunt HJ, Ray NC, Hynd G, Sutton J, Sajad M, O'Connor E, Ahmed S, Lockey P, Daly S and Buckley G et al.. (2012) Discovery of a novel non-steroidal GR antagonist with in vivo efficacy in the olanzapine-induced weight gain model in the rat. Bioorg Med Chem Lett 22: 7376-80 [PMID:23131342]

154. Hurley DM, Accili D, Stratakis CA, Karl M, Vamvakopoulos N, Rorer E, Constantine K, Taylor SI and Chrousos GP. (1991) Point mutation causing a single amino acid substitution in the hormone binding domain of the glucocorticoid receptor in familial glucocorticoid resistance. J Clin Invest 87: 680-6 [PMID:1704018]

155. Iitsuka Y, Bock A, Nguyen DD, Samango-Sprouse CA, Simpson JL and Bischoff FZ. (2001) Evidence of skewed X-chromosome inactivation in 47,XXY and 48,XXYY Klinefelter patients. Am J Med Genet 98: 25-31 [PMID:11426451]

156. Ismail PM, Amato P, Soyal SM, DeMayo FJ, Conneely OM, O'Malley BW and Lydon JP. (2003) Progesterone involvement in breast development and tumorigenesis--as revealed by progesterone receptor "knockout" and "knockin" mouse models. Steroids 68: 779-87 [PMID:14667968]

157. Ito K, Adachi S, Iwakami R, Yasuda H, Muto Y, Seki N and Okano Y. (2001) N-Terminally extended human ubiquitin-conjugating enzymes (E2s) mediate the ubiquitination of RING-finger proteins, ARA54 and RNF8. Eur J Biochem 268: 2725-32 [PMID:11322894]

158. Jaffe IZ, Tintut Y, Newfell BG, Demer LL and Mendelsohn ME. (2007) Mineralocorticoid receptor activation promotes vascular cell calcification. Arterioscler Thromb Vasc Biol 27: 799-805 [PMID:17234727]

159. Jeong JW, Lee KY, Kwak I, White LD, Hilsenbeck SG, Lydon JP and DeMayo FJ. (2005) Identification of murine uterine genes regulated in a ligand-dependent manner by the progesterone receptor. Endocrinology 146: 3490-505 [PMID:15845616]

160. Jerjes WK, Cleare AJ, Wood PJ and Taylor NF. (2006) Assessment of subtle changes in glucocorticoid negative feedback using prednisolone: comparison of salivary free cortisol and urinary cortisol metabolites as endpoints. Clin Chim Acta 364: 279-86 [PMID:16168400]

161. Johansson A, Helou K and Levan G. (1998) Cytogenetic localization of cancer-related genes in the rat and comparative mapping studies in human and mouse. Cytogenet Cell Genet 81: 217-21 [PMID:9730607]

162. Jonat C, Rahmsdorf HJ, Park KK, Cato AC, Gebel S, Ponta H and Herrlich P. (1990) Antitumor promotion and antiinflammation: down-modulation of AP-1 (Fos/Jun) activity by glucocorticoid hormone. Cell 62: 1189-204 [PMID:2169351]

163. Jung ME, Ouk S, Yoo D, Sawyers CL, Chen C, Tran C and Wongvipat J. (2010) Structure-activity relationship for thiohydantoin androgen receptor antagonists for castration-resistant prostate cancer (CRPC). J Med Chem 53: 2779-96 [PMID:20218717] 
164. Kamei Y, Xu L, Heinzel T, Torchia J, Kurokawa R, Gloss B, Lin SC, Heyman RA, Rose DW, Glass CK and Rosenfeld MG. (1996) A CBP integrator complex mediates transcriptional activation and AP-1 inhibition by nuclear receptors. Cell 85: 403-14 [PMID:8616895]

165. Kanelakis KC, Shewach DS and Pratt WB. (2002) Nucleotide binding states of hsp70 and hsp90 during sequential steps in the process of glucocorticoid receptor.hsp90 heterocomplex assembly. J Biol Chem 277: 33698-703 [PMID:12093808]

166. Kang HY, Yeh S, Fujimoto N and Chang C. (1999) Cloning and characterization of human prostate coactivator ARA54, a novel protein that associates with the androgen receptor. J Biol Chem 274: 8570-6 [PMID:10085091]

167. Kang Z, Pirskanen A, Jänne OA and Palvimo JJ. (2002) Involvement of proteasome in the dynamic assembly of the androgen receptor transcription complex. J Biol Chem 277: 48366-71 [PMID:12376534]

168. Karl M, Lamberts SW, Detera-Wadleigh SD, Encio IJ, Stratakis CA, Hurley DM, Accili D and Chrousos GP. (1993) Familial glucocorticoid resistance caused by a splice site deletion in the human glucocorticoid receptor gene. J Clin Endocrinol Metab 76: 683-9 [PMID:8445027]

169. Kasai Y. (1990) Two naturally-occurring isoforms and their expression of a glucocorticoid receptor gene from an androgen-dependent mouse tumor. FEBS Lett 274: 99-102 [PMID:2253790]

170. Kassel O, Sancono A, Krätzschmar J, Kreft B, Stassen M and Cato AC. (2001) Glucocorticoids inhibit MAP kinase via increased expression and decreased degradation of MKP-1. EMBO J 20: 7108-16 [PMID:11742987]

171. Kastner P, Krust A, Turcotte B, Stropp U, Tora L, Gronemeyer H and Chambon P. (1990) Two distinct estrogen-regulated promoters generate transcripts encoding the two functionally different human progesterone receptor forms A and B. EMBO J 9: 1603-14 [PMID:2328727]

172. Kato M, Furuie H, Shimizu T, Miyazaki A, Kobayashi F and Ishizuka H. (2018) Single- and multiple-dose escalation study to assess pharmacokinetics, pharmacodynamics and safety of oral esaxerenone in healthy Japanese subjects. Br J Clin Pharmacol 84: 1821-1829 [PMID:29688582]

173. Kauppi B, Jakob C, Färnegårdh M, Yang J, Ahola H, Alarcon M, Calles K, Engström O, Harlan J, Muchmore S, Ramqvist AK, Thorell S, Ohman L, Greer J, Gustafsson JA, Carlstedt-Duke J and Carlquist M. (2003) The three-dimensional structures of antagonistic and agonistic forms of the glucocorticoid receptor ligand-binding domain: RU-486 induces a transconformation that leads to active antagonism. J Biol Chem 278: 22748-54 [PMID:12686538]

174. Keller DW, Wiest WG, Askin FB, Johnson LW and Strickler RC. (1979) Pseudocorpus luteum insufficiency: a local defect of progesterone action on endometrial stroma. J Clin Endocrinol Metab 48: 127-32 [PMID:217888]

175. Kerkhofs S, Dubois V, De Gendt K, Helsen C, Clinckemalie L, Spans L, Schuit F, Boonen S, Vanderschueren D and Saunders PT et al.. (2012) A role for selective androgen response elements in the development of the epididymis and the androgen control of the $5 \alpha$ reductase II gene. FASEB J 26: 4360-72 [PMID:22798427]

176. Khan JA, Tikad A, Fay M, Hamze A, Fagart J, Chabbert-Buffet N, Meduri G, Amazit L, Brion JD and Alami M et al.. (2013) A new strategy for selective targeting of progesterone receptor with passive antagonists. Mol Endocrinol 27: 909-24 [PMID:23579486]

177. Khan OY, Fu G, Ismail A, Srinivasan S, Cao X, Tu Y, Lu S and Nawaz Z. (2006) Multifunction steroid receptor coactivator, E6-associated protein, is involved in development of the prostate gland. Mol Endocrinol 20: 544-59 [PMID:16254014]

178. Kino T, Souvatzoglou E, De Martino MU, Tsopanomihalu M, Wan Y and Chrousos GP. (2003) Protein 14-3-3sigma interacts with and favors cytoplasmic subcellular localization of the glucocorticoid receptor, acting as a negative regulator of the glucocorticoid signaling pathway. $J$ Biol Chem 278: 25651-6 [PMID:12730237]

179. Kino T, Stauber RH, Resau JH, Pavlakis GN and Chrousos GP. (2001) Pathologic human GR mutant has a transdominant negative effect on the wild-type GR by inhibiting its translocation into the nucleus: importance of the ligand-binding domain for intracellular GR trafficking. J Clin Endocrinol Metab 86: 5600-8 [PMID:11701741]

180. Kinoyama I, Taniguchi N, Toyoshima A, Nozawa E, Kamikubo T, Imamura M, Matsuhisa A, Samizu K, Kawanimani E and Niimi T et al.. (2006) (+)-(2R,5S)-4-[4-cyano-3(trifluoromethyl)phenyl]-2,5-dimethyl-N-[6-(trifluoromethyl)pyridin-3- yl]piperazine-1carboxamide (YM580) as an orally potent and peripherally selective nonsteroidal androgen receptor antagonist. J Med Chem 49: 716-26 [PMID:16420057]

181. Kitagawa H, Yanagisawa J, Fuse H, Ogawa S, Yogiashi Y, Okuno A, Nagasawa H, Nakajima T, Matsumoto T and Kato S. (2002) Ligand-selective potentiation of rat mineralocorticoid receptor activation function 1 by a CBP-containing histone acetyltransferase complex. Mol Cell Biol 22: 3698-706 [PMID:11997506]

182. Knutti D, Kaul A and Kralli A. (2000) A tissue-specific coactivator of steroid receptors, identified in a functional genetic screen. Mol Cell Biol 20: 2411-22 [PMID:10713165]

183. Kolla V and Litwack G. (2000) Transcriptional regulation of the human Na/K ATPase via the 
human mineralocorticoid receptor. Mol Cell Biochem 204: 35-40 [PMID:10718622]

184. Kolla V, Robertson NM and Litwack G. (1999) Identification of a mineralocorticoid/glucocorticoid response element in the human Na/K ATPase alpha1 gene promoter. Biochem Biophys Res Commun 266: 5-14 [PMID:10581156]

185. Koper JW, Stolk RP, de Lange P, Huizenga NA, Molijn GJ, Pols HA, Grobbee DE, Karl M, de Jong FH and Brinkmann AO et al.. (1997) Lack of association between five polymorphisms in the human glucocorticoid receptor gene and glucocorticoid resistance. Hum Genet 99: 663-8 [PMID:9150737]

186. Kotula-Balak M, Bablok L, Fracki S, Jankowska A and Bilińska B. (2004) Immunoexpression of androgen receptors and aromatase in testes of patient with Klinefelter's syndrome. Folia Histochem Cytobiol 42: 215-20 [PMID:15704647]

187. Krieg M, Dennis M and Voigt KD. (1976) Comparison between the binding of 19nortestosterone, 5alpha-dihydrotestosterone and testosterone in rat prostate and bulbocavernosus/levator ani muscle. J Endocrinol 70: 379-87 [PMID:978099]

188. Krozowski ZS and Funder JW. (1983) Renal mineralocorticoid receptors and hippocampal corticosterone-binding species have identical intrinsic steroid specificity. Proc Natl Acad Sci USA 80: 6056-60 [PMID:6310613]

189. Krämer EA, Seeger H, Krämer B, Wallwiener D and Mueck AO. (2005) The effects of progesterone, medroxyprogesterone acetate, and norethisterone on growth factor- and estradiol-treated human cancerous and noncancerous breast cells. Menopause 12: 468-74 [PMID:16037763]

190. Kubli-Garfias C, González-Flores O, Gómora-Arrati P, González-Mariscal G, Vázquez-Ramírez R and Beyer C. (2013) Bimodal binding and free energy of the progesterone receptor in the induction of female sexual receptivity by progesterone and synthetic progestins. J Steroid Biochem Mol Biol 133: 43-50 [PMID:22960752]

191. Kugler DG, Mittelstadt PR, Ashwell JD, Sher A and Jankovic D. (2013) CD4+ T cells are trigger and target of the glucocorticoid response that prevents lethal immunopathology in toxoplasma infection. J Exp Med 210: 1919-27 [PMID:23980098]

192. Kullmann M, Schneikert J, Moll J, Heck S, Zeiner M, Gehring U and Cato AC. (1998) RAP46 is a negative regulator of glucocorticoid receptor action and hormone-induced apoptosis. J Biol Chem 273: 14620-5 [PMID:9603979]

193. Kumar R, Moure CM, Khan SH, Callaway C, Grimm SL, Goswami D, Griffin PR and Edwards DP. (2013) Regulation of the structurally dynamic N-terminal domain of progesterone receptor by protein-induced folding. J Biol Chem 288: 30285-99 [PMID:23995840]

194. Kuppusamy M, Gomez-Sanchez EP, Beloate LN, Plonczynski M, Naray-Fejes-Toth A, Fejes-Toth G and Gomez-Sanchez CE. (2017) Interaction of the Mineralocorticoid Receptor With RACK1 and Its Role in Aldosterone Signaling. Endocrinology 158: 2367-2375 [PMID:28472300]

195. Langer K, Moser D, Otto T, Wolf OT and Kumsta R. (2019) Cortisol modulates the engagement of multiple memory systems: Exploration of a common NR3C2 polymorphism. Psychoneuroendocrinology 107: 133-140 [PMID:31128569]

196. Lanz RB, McKenna NJ, Onate SA, Albrecht U, Wong J, Tsai SY, Tsai MJ and O'Malley BW. (1999) A steroid receptor coactivator, SRA, functions as an RNA and is present in an SRC-1 complex. Cell 97: 17-27 [PMID:10199399]

197. Le Billan F, Khan JA, Lamribet K, Viengchareun S, Bouligand J, Fagart J and Lombès M. (2015) Cistrome of the aldosterone-activated mineralocorticoid receptor in human renal cells. FASEB J 29: 3977-89 [PMID:26054365]

198. Lee IR, Dawson SA, Wetherall JD and Hahnel R. (1987) Sex hormone-binding globulin secretion by human hepatocarcinoma cells is increased by both estrogens and androgens. J Clin Endocrinol Metab 64: 825-31 [PMID:3029159]

199. Lee SK, Anzick SL, Choi JE, Bubendorf L, Guan XY, Jung YK, Kallioniemi OP, Kononen J, Trent JM, Azorsa D, Jhun BH, Cheong JH, Lee YC, Meltzer PS and Lee JW. (1999) A nuclear factor, ASC-2, as a cancer-amplified transcriptional coactivator essential for ligand-dependent transactivation by nuclear receptors in vivo. J Biol Chem 274: 34283-93 [PMID:10567404]

200. Leonhardt SA, Altmann M and Edwards DP. (1998) Agonist and antagonists induce homodimerization and mixed ligand heterodimerization of human progesterone receptors in vivo by a mammalian two-hybrid assay. Mol Endocrinol 12: 1914-30 [PMID:9849965]

201. Lesouhaitier O, Chiappe A and Rossier MF. (2001) Aldosterone increases T-type calcium currents in human adrenocarcinoma (H295R) cells by inducing channel expression. Endocrinology 142: 4320-30 [PMID:11564691]

202. Li JJ, Iula DM, Nguyen MN, Hu LY, Dettling D, Johnson TR, Du DY, Shanmugasundaram V, Van Camp JA and Wang $Z$ et al.. (2008) Rational design and synthesis of 4-((1R,2R)-2hydroxycyclohexyl)-2(trifluoromethyl)benzonitrile (PF-998425), a novel, nonsteroidal androgen receptor antagonist devoid of phototoxicity for dermatological indications. J Med Chem 51: 7010-4 [PMID:18921992]

203. Li X, Wong J, Tsai SY, Tsai MJ and O'Malley BW. (2003) Progesterone and glucocorticoid 
receptors recruit distinct coactivator complexes and promote distinct patterns of local chromatin modification. Mol Cell Biol 23: 3763-73 [PMID:12748280]

204. Liberman AC, Refojo D, Druker J, Toscano M, Rein T, Holsboer F and Arzt E. (2007) The activated glucocorticoid receptor inhibits the transcription factor T-bet by direct protein-protein interaction. FASEB J 21: 1177-88 [PMID:17215482]

205. Liegibel UM, Sommer U, Boercsoek I, Hilscher U, Bierhaus A, Schweikert HU, Nawroth P and Kasperk C. (2003) Androgen receptor isoforms AR-A and AR-B display functional differences in cultured human bone cells and genital skin fibroblasts. Steroids 68: 1179-87 [PMID:14643880]

206. Lin B, Ferguson C, White JT, Wang S, Vessella R, True LD, Hood L and Nelson PS. (1999) Prostate-localized and androgen-regulated expression of the membrane-bound serine protease TMPRSS2. Cancer Res 59: 4180-4 [PMID:10485450]

207. Lin HY, Xu Q, Yeh S, Wang RS, Sparks JD and Chang C. (2005) Insulin and leptin resistance with hyperleptinemia in mice lacking androgen receptor. Diabetes 54: 1717-25 [PMID:15919793]

208. Lind U, Greenidge P, Gillner M, Koehler KF, Wright A and Carlstedt-Duke J. (2000) Functional probing of the human glucocorticoid receptor steroid-interacting surface by site-directed mutagenesis. Gln-642 plays an important role in steroid recognition and binding. J Biol Chem 275: 19041-9 [PMID:10747884]

209. Linja MJ and Visakorpi T. (2004) Alterations of androgen receptor in prostate cancer. J Steroid Biochem Mol Biol 92: 255-64 [PMID:15663988]

210. Liu G, Sprenger C, Sun S, Epilepsia KS, Haugk K, Zhang X, Coleman I, Nelson PS and Plymate S. (2013) AR variant ARv567es induces carcinogenesis in a novel transgenic mouse model of prostate cancer. Neoplasia 15: 1009-17 [PMID:24027426]

211. Liu W, Wang J, Sauter NK and Pearce D. (1995) Steroid receptor heterodimerization demonstrated in vitro and in vivo. Proc Natl Acad Sci USA 92: 12480-4 [PMID:8618925]

212. Liu Z, Auboeuf D, Wong J, Chen JD, Tsai SY, Tsai MJ and O'Malley BW. (2002) Coactivator/corepressor ratios modulate PR-mediated transcription by the selective receptor modulator RU486. Proc Natl Acad Sci USA 99: 7940-4 [PMID:12048256]

213. Liu Z, Wong J, Tsai SY, Tsai MJ and O'Malley BW. (1999) Steroid receptor coactivator-1 (SRC-1) enhances ligand-dependent and receptor-dependent cell-free transcription of chromatin. Proc Natl Acad Sci USA 96: 9485-90 [PMID:10449719]

214. Lu NZ and Cidlowski JA. (2005) Translational regulatory mechanisms generate N-terminal glucocorticoid receptor isoforms with unique transcriptional target genes. Mol Cell 18: 331-42 [PMID:15866175]

215. Lu NZ, Wardell SE, Burnstein KL, Defranco D, Fuller PJ, Giguere V, Hochberg RB, McKay L, Renoir JM, Weigel NL, Wilson EM, McDonnell DP and Cidlowski JA. (2006) International Union of Pharmacology. LXV. The pharmacology and classification of the nuclear receptor superfamily: glucocorticoid, mineralocorticoid, progesterone, and androgen receptors. Pharmacol Rev 58: 782-97 [PMID:17132855]

216. Lydon JP, DeMayo FJ, Funk CR, Mani SK, Hughes AR, Montgomery CA, Shyamala G, Conneely OM and O'Malley BW. (1995) Mice lacking progesterone receptor exhibit pleiotropic reproductive abnormalities. Genes Dev 9: 2266-78 [PMID:7557380]

217. Lyon MF and Hawkes SG. (1970) X-linked gene for testicular feminization in the mouse. Nature 227: 1217-9 [PMID:5452809]

218. MacLean HE, Choi WT, Rekaris G, Warne GL and Zajac JD. (1995) Abnormal androgen receptor binding affinity in subjects with Kennedy's disease (spinal and bulbar muscular atrophy). J Clin Endocrinol Metab 80: 508-16 [PMID:7852512]

219. Madauss KP, Bledsoe RK, Mclay I, Stewart EL, Uings IJ, Weingarten G and Williams SP. (2008) The first X-ray crystal structure of the glucocorticoid receptor bound to a non-steroidal agonist. Bioorg Med Chem Lett 18: 6097-9 [PMID:18952422]

220. Majumder S, Liu Y, Ford 3rd OH, Mohler JL and Whang YE. (2006) Involvement of arginine methyltransferase CARM1 in androgen receptor function and prostate cancer cell viability. Prostate 66: 1292-301 [PMID:16705743]

221. Mallick S and Horwitz SB. (1997) Transcriptional regulation of the murine multidrug resistance gene mdr1b by progesterone occurs via an indirect mechanism. DNA Cell Biol 16: 807-18 [PMID:9260924]

222. Manfredi MC, Bi Y, Nirschl AA, Sutton JC, Seethala R, Golla R, Beehler BC, Sleph PG, Grover GJ and Ostrowski J et al.. (2007) Synthesis and SAR of tetrahydropyrrolo[1,2-b][1,2,5]thiadiazol2(3H)-one 1,1-dioxide analogues as highly potent selective androgen receptor modulators. Bioorg Med Chem Lett 17: 4487-90 [PMID:17574413]

223. Mangal RK, Wiehle RD, Poindexter AN and Weigel NL. (1997) Differential expression of uterine progesterone receptor forms A and B during the menstrual cycle. J Steroid Biochem Mol Biol 63: 195-202 [PMID:9459185]

224. Marivoet S, Van Dijck P, Verhoeven G and Heyns W. (1992) Interaction of the 90-kDa heat shock protein with native and in vitro translated androgen receptor and receptor fragments. Mol Cell Endocrinol 88: 165-74 [PMID:1459337] 
225. Maruyama K, Nakamura M, Tomoshige S, Sugita K, Makishima M, Hashimoto Y and Ishikawa M. (2013) Structure-activity relationships of bisphenol A analogs at estrogen receptors (ERs): discovery of an ERo-selective antagonist. Bioorg Med Chem Lett 23: 4031-6 [PMID:23768907]

226. Mattei MG, Krust A, Stropp U, Mattei JF and Chambon P. (1988) Assignment of the human progesterone receptor to the q22 band of chromosome 11. Hum Genet 78: 96-7 [PMID:3338797]

227. McCurley A, Pires PW, Bender SB, Aronovitz M, Zhao MJ, Metzger D, Chambon P, Hill MA, Dorrance AM and Mendelsohn ME et al.. (2012) Direct regulation of blood pressure by smooth muscle cell mineralocorticoid receptors. Nat Med 18: 1429-33 [PMID:22922412]

228. McKenna NJ, Xu J, Nawaz Z, Tsai SY, Tsai MJ and O'Malley BW. (1999) Nuclear receptor coactivators: multiple enzymes, multiple complexes, multiple functions. J Steroid Biochem Mol Biol 69: 3-12 [PMID:10418975]

229. Mendonca BB, Leite MV, de Castro M, Kino T, Elias LL, Bachega TA, Arnhold IJ, Chrousos GP and Latronico AC. (2002) Female pseudohermaphroditism caused by a novel homozygous missense mutation of the GR gene. J Clin Endocrinol Metab 87: 1805-9 [PMID:11932321]

230. Mestayer C, Blanchère M, Jaubert F, Dufour B and Mowszowicz I. (2003) Expression of androgen receptor coactivators in normal and cancer prostate tissues and cultured cell lines. Prostate 56: 192-200 [PMID:12772188]

231. Miesfeld R, Rusconi S, Godowski PJ, Maler BA, Okret S, Wikström AC, Gustafsson JA and Yamamoto KR. (1986) Genetic complementation of a glucocorticoid receptor deficiency by expression of cloned receptor cDNA. Cell 46: 389-99 [PMID:3755378]

232. Millan DS, Ballard SA, Chunn S, Dybowski JA, Fulton CK, Glossop PA, Guillabert E, Hewson CA, Jones RM and Lamb DJ et al.. (2011) Design and synthesis of long acting inhaled corticosteroids for the treatment of asthma. Bioorg Med Chem Lett 21: 5826-30 [PMID:21880489]

233. Mitchell MD, Lytton FD and Varticovski L. (1988) Paradoxical stimulation of both lipocortin and prostaglandin production in human amnion cells by dexamethasone. Biochem Biophys Res Commun 151: 137-41 [PMID:2964820]

234. Miyamoto H, Rahman M, Takatera H, Kang HY, Yeh S, Chang HC, Nishimura K, Fujimoto N and Chang C. (2002) A dominant-negative mutant of androgen receptor coregulator ARA54 inhibits androgen receptor-mediated prostate cancer growth. J Biol Chem 277: 4609-17 [PMID:11673464]

235. Miyoshi $Y$, Ishiguro H, Uemura H, Fujinami K, Miyamoto H, Miyoshi $Y$, Kitamura $H$ and Kubota Y. (2003) Expression of AR associated protein 55 (ARA55) and androgen receptor in prostate cancer. Prostate 56: 280-6 [PMID:12858356]

236. Moalli PA, Pillay S, Krett NL and Rosen ST. (1993) Alternatively spliced glucocorticoid receptor messenger RNAs in glucocorticoid-resistant human multiple myeloma cells. Cancer Res 53: 3877-9 [PMID:8358712]

237. Mohler ML, Bohl CE, Jones A, Coss CC, Narayanan R, He Y, Hwang DJ, Dalton JT and Miller DD. (2009) Nonsteroidal selective androgen receptor modulators (SARMs): dissociating the anabolic and androgenic activities of the androgen receptor for therapeutic benefit. J Med Chem 52: 3597-617 [PMID:19432422]

238. Moilanen AM, Riikonen R, Oksala R, Ravanti L, Aho E, Wohlfahrt G, Nykänen PS, Törmäkangas OP, Palvimo JJ and Kallio PJ. (2015) Discovery of ODM-201, a new-generation androgen receptor inhibitor targeting resistance mechanisms to androgen signaling-directed prostate cancer therapies. Sci Rep 5: 12007 [PMID:26137992]

239. Morale MC, Batticane N, Gallo F, Barden N and Marchetti B. (1995) Disruption of hypothalamicpituitary-adrenocortical system in transgenic mice expressing type II glucocorticoid receptor antisense ribonucleic acid permanently impairs $\mathrm{T}$ cell function: effects on $\mathrm{T}$ cell trafficking and $\mathrm{T}$ cell responsiveness during postnatal development. Endocrinology 136: 3949-60 [PMID:7649104]

240. Murai-Takeda A, Shibata H, Kurihara I, Kobayashi S, Yokota K, Suda N, Mitsuishi Y, Jo R, Kitagawa H and Kato S et al.. (2010) NF-YC functions as a corepressor of agonist-bound mineralocorticoid receptor. J Biol Chem 285: 8084-93 [PMID:20054001]

241. Müller JM, Isele U, Metzger E, Rempel A, Moser M, Pscherer A, Breyer T, Holubarsch C, Buettner R and Schüle R. (2000) FHL2, a novel tissue-specific coactivator of the androgen receptor. EMBO J 19: 359-69 [PMID:10654935]

242. Nagy L, Kao HY, Chakravarti D, Lin RJ, Hassig CA, Ayer DE, Schreiber SL and Evans RM. (1997) Nuclear receptor repression mediated by a complex containing SMRT, mSin3A, and histone deacetylase. Cell 89: 373-80 [PMID:9150137]

243. Naylor SL, Helen-Davis D, Hughes MR, O'Malley BW and Lalley PA. (1989) The progesterone receptor gene is on mouse chromosome 9. Cytogenet Cell Genet 51: 1051

244. Neuschmid-Kaspar F, Gast A, Peterziel H, Schneikert J, Muigg A, Ransmayr G, Klocker H, Bartsch G and Cato AC. (1996) CAG-repeat expansion in androgen receptor in Kennedy's disease is not a loss of function mutation. Mol Cell Endocrinol 117: 149-56 [PMID:8737374]

245. Nickisch K, Elger W, Santhamma B, Garfield R, Killeen Z, Amelkina O, Schneider B and Meister R. (2014) Synthesis and biological evaluation of 11' imidazolyl antiprogestins and 
mesoprogestins. Steroids 92: 45-55 [PMID:25174783]

246. Nishi M. (2010) Imaging of transcription factor trafficking in living cells: lessons from corticosteroid receptor dynamics. Methods Mol Biol 647: 199-212 [PMID:20694669]

247. Nishi M and Kawata M. (2007) Dynamics of glucocorticoid receptor and mineralocorticoid receptor: implications from live cell imaging studies. Neuroendocrinology 85: 186-92 [PMID:17446698]

248. Nishi M, Tanaka M, Matsuda K, Sunaguchi M and Kawata M. (2004) Visualization of glucocorticoid receptor and mineralocorticoid receptor interactions in living cells with GFPbased fluorescence resonance energy transfer. J Neurosci 24: 4918-27 [PMID:15163683]

249. No authors listed. (2014) Retraction for Kitagawa et al., Ligand-selective potentiation of rat mineralocorticoid receptor activation function 1 by a CBP-containing histone acetyltransferase complex. Mol Cell Biol 34: 916 [PMID:24509261]

250. Náray-Fejes-Tóth A, Snyder PM and Fejes-Tóth G. (2004) The kidney-specific WNK1 isoform is induced by aldosterone and stimulates epithelial sodium channel-mediated $\mathrm{Na}+$ transport. Proc Natl Acad Sci USA 101: 17434-9 [PMID:15583131]

251. Oakley RH, Cruz-Topete D, He B, Foley JF, Myers PH, Xu X, Gomez-Sanchez CE, Chambon P, Willis MS and Cidlowski JA. (2019) Cardiomyocyte glucocorticoid and mineralocorticoid receptors directly and antagonistically regulate heart disease in mice. Sci Signal 12 [PMID:30992401]

252. Oakley RH, Ren R, Cruz-Topete D, Bird GS, Myers PH, Boyle MC, Schneider MD, Willis MS and Cidlowski JA. (2013) Essential role of stress hormone signaling in cardiomyocytes for the prevention of heart disease. Proc Natl Acad Sci USA 110: 17035-40 [PMID:24082121]

253. Oakley RH, Sar M and Cidlowski JA. (1996) The human glucocorticoid receptor beta isoform. Expression, biochemical properties, and putative function. J Biol Chem 271: 9550-9 [PMID:8621628]

254. Oakley RH, Webster JC, Sar M, Parker CR and Cidlowski JA. (1997) Expression and subcellular distribution of the beta-isoform of the human glucocorticoid receptor. Endocrinology 138: 502838 [PMID:9348235]

255. Obr AE, Grimm SL, Bishop KA, Pike JW, Lydon JP and Edwards DP. (2013) Progesterone receptor and Stat5 signaling cross talk through RANKL in mammary epithelial cells. Mol Endocrinol 27: 1808-24 [PMID:24014651]

256. Obradović D, Tirard M, Némethy Z, Hirsch O, Gronemeyer H and Almeida OF. (2004) DAXX, FLASH, and FAF-1 modulate mineralocorticoid and glucocorticoid receptor-mediated transcription in hippocampal cells--toward a basis for the opposite actions elicited by two nuclear receptors? Mol Pharmacol 65: 761-9 [PMID:14978255]

257. Odermatt A and Kratschmar DV. (2012) Tissue-specific modulation of mineralocorticoid receptor function by $11 \beta$-hydroxysteroid dehydrogenases: an overview. Mol Cell Endocrinol 350: 168-86 [PMID:21820034]

258. Oitzl MS, Reichardt HM, Joëls M and de Kloet ER. (2001) Point mutation in the mouse glucocorticoid receptor preventing DNA binding impairs spatial memory. Proc Natl Acad Sci USA 98: 12790-5 [PMID:11606764]

259. Okamoto K and Isohashi F. (2005) Macromolecular translocation inhibitor II (Zn(2+)-binding protein, parathymosin) interacts with the glucocorticoid receptor and enhances transcription in vivo. J Biol Chem 280: 36986-93 [PMID:16150697]

260. Ong GSY, Cole TJ, Tesch GH, Morgan J, Dowling JK, Mansell A, Fuller PJ and Young MJ. (2020) Novel mineralocorticoid receptor mechanisms regulate cardiac tissue inflammation in male mice. J Endocrinol 246: 123-134 [PMID:32464598]

261. Opherk C, Tronche F, Kellendonk C, Kohlmüller D, Schulze A, Schmid W and Schütz G. (2004) Inactivation of the glucocorticoid receptor in hepatocytes leads to fasting hypoglycemia and ameliorates hyperglycemia in streptozotocin-induced diabetes mellitus. Mol Endocrinol 18: 1346-53 [PMID:15031319]

262. Ou XM, Storring JM, Kushwaha N and Albert PR. (2001) Heterodimerization of mineralocorticoid and glucocorticoid receptors at a novel negative response element of the 5HT1A receptor gene. J Biol Chem 276: 14299-307 [PMID:11278286]

263. Oñate SA, Prendergast P, Wagner JP, Nissen M, Reeves R, Pettijohn DE and Edwards DP. (1994) The DNA-bending protein HMG-1 enhances progesterone receptor binding to its target DNA sequences. Mol Cell Biol 14: 3376-91 [PMID:8164686]

264. Oñate SA, Tsai SY, Tsai MJ and O'Malley BW. (1995) Sequence and characterization of a coactivator for the steroid hormone receptor superfamily. Science 270: 1354-7 [PMID:7481822]

265. Parandoosh Z, Crombie DL, Tetzke TA, Hayes JS, Heap RB and Wang MW. (1995) Progesterone and oestrogen receptors in the decidualized mouse uterus and effects of different types of antiprogesterone treatment. J Reprod Fertil 105: 215-20 [PMID:8568763]

266. Pascual-Le Tallec L, Demange C and Lombès M. (2004) Human mineralocorticoid receptor A and B protein forms produced by alternative translation sites display different transcriptional activities. Eur J Endocrinol 150: 585-90 [PMID:15080790] 
267. Pascual-Le Tallec L, Simone F, Viengchareun S, Meduri G, Thirman MJ and Lombès M. (2005) The elongation factor ELL (eleven-nineteen lysine-rich leukemia) is a selective coregulator for steroid receptor functions. Mol Endocrinol 19: 1158-69 [PMID:15650021]

268. Patel PD, Sherman TG, Goldman DJ and Watson SJ. (1989) Molecular cloning of a mineralocorticoid (type I) receptor complementary DNA from rat hippocampus. Mol Endocrinol 3: 1877-85 [PMID:2558305]

269. Petit-Topin I, Turque N, Fagart J, Fay M, Ulmann A, Gainer E and Rafestin-Oblin ME. (2009) Met909 plays a key role in the activation of the progesterone receptor and also in the high potency of 13-ethyl progestins. Mol Pharmacol 75: 1317-24 [PMID:19289570]

270. Petrovich E, Asher C and Garty H. (2014) Induction of FKBP51 by aldosterone in intestinal epithelium. J Steroid Biochem Mol Biol 139: 78-87 [PMID:24139875]

271. Piotrowski DW. (2012) Mineralocorticoid receptor antagonists for the treatment of hypertension and diabetic nephropathy. J Med Chem 55: 7957-66 [PMID:22866979]

272. Pollow K, Juchem M, Elger W, Jacobi N, Hoffmann G and Möbus V. (1992) Dihydrospirorenone (ZK30595): a novel synthetic progestagen--characterization of binding to different receptor proteins. Contraception 46: 561-74 [PMID:1493716]

273. Poulsen SB, Limbutara K, Fenton RA, Pisitkun T and Christensen BM. (2018) RNA sequencing of kidney distal tubule cells reveals multiple mediators of chronic aldosterone action. Physiol Genomics 50: 343-354 [PMID:29521601]

274. Powell SM, Christiaens V, Voulgaraki D, Waxman J, Claessens F and Bevan CL. (2004) Mechanisms of androgen receptor signalling via steroid receptor coactivator-1 in prostate. Endocr Relat Cancer 11: 117-30 [PMID:15027889]

275. Pratt WB. (1993) The role of heat shock proteins in regulating the function, folding, and trafficking of the glucocorticoid receptor. J Biol Chem 268: 21455-8 [PMID:8407992]

276. Pratt WB, Galigniana MD, Morishima Y and Murphy PJ. (2004) Role of molecular chaperones in steroid receptor action. Essays Biochem 40: 41-58 [PMID:15242338]

277. Pratt WB and Toft DO. (1997) Steroid receptor interactions with heat shock protein and immunophilin chaperones. Endocr Rev 18: 306-60 [PMID:9183567]

278. Rachez C, Lemon BD, Suldan Z, Bromleigh V, Gamble M, Näär AM, Erdjument-Bromage H, Tempst $P$ and Freedman LP. (1999) Ligand-dependent transcription activation by nuclear receptors requires the DRIP complex. Nature 398: 824-8 [PMID:10235266]

279. Rafestin-Oblin ME, Couette B, Radanyi C, Lombes M and Baulieu EE. (1989) Mineralocorticosteroid receptor of the chick intestine. Oligomeric structure and transformation. J Biol Chem 264: 9304-9 [PMID:2542305]

280. Ramamoorthy S and Cidlowski JA. (2013) Ligand-induced repression of the glucocorticoid receptor gene is mediated by an NCoR1 repression complex formed by long-range chromatin interactions with intragenic glucocorticoid response elements. Mol Cell Biol 33: 1711-22 [PMID:23428870]

281. Rashmi P, Colussi G, Ng M, Wu X, Kidwai A and Pearce D. (2017) Glucocorticoid-induced leucine zipper protein regulates sodium and potassium balance in the distal nephron. Kidney Int 91: 1159-1177 [PMID:28094030]

282. Rauch A, Seitz S, Baschant U, Schilling AF, Illing A, Stride B, Kirilov M, Mandic V, Takacz A and Schmidt-Ullrich R et al.. (2010) Glucocorticoids suppress bone formation by attenuating osteoblast differentiation via the monomeric glucocorticoid receptor. Cell Metab 11: 517-31 [PMID:20519123]

283. Ray DW, Davis JR, White A and Clark AJ. (1996) Glucocorticoid receptor structure and function in glucocorticoid-resistant small cell lung carcinoma cells. Cancer Res 56: 3276-80 [PMID:8764121]

284. Reeves EK, Hoffman EP, Nagaraju K, Damsker JM and McCall JM. (2013) VBP15: preclinical characterization of a novel anti-inflammatory delta 9,11 steroid. Bioorg Med Chem 21: 2241-9 [PMID:23498916]

285. Reichardt HM, Tuckermann JP, Göttlicher M, Vujic M, Weih F, Angel P, Herrlich P and Schütz G. (2001) Repression of inflammatory responses in the absence of DNA binding by the glucocorticoid receptor. EMBO J 20: 7168-73 [PMID:11742993]

286. Rennie PS, Bruchovsky N, Leco KJ, Sheppard PC, McQueen SA, Cheng H, Snoek R, Hamel A, Bock ME and MacDonald BS. (1993) Characterization of two cis-acting DNA elements involved in the androgen regulation of the probasin gene. Mol Endocrinol 7: 23-36 [PMID:8446105]

287. Resch JM, Fenselau H, Madara JC, Wu C, Campbell JN, Lyubetskaya A, Dawes BA, Tsai LT, Li MM and Livneh Y et al.. (2017) Aldosterone-Sensing Neurons in the NTS Exhibit StateDependent Pacemaker Activity and Drive Sodium Appetite via Synergy with Angiotensin II Signaling. Neuron 96: 190-206.e7 [PMID:28957668]

288. Reutens AT, Fu M, Wang C, Albanese C, McPhaul MJ, Sun Z, Balk SP, Jänne OA, Palvimo JJ and Pestell RG. (2001) Cyclin D1 binds the androgen receptor and regulates hormone-dependent signaling in a p300/CBP-associated factor (P/CAF)-dependent manner. Mol Endocrinol 15: 797811 [PMID:11328859] 
289. Rewinkel J, Enthoven M, Golstein I, van der Rijst M, Scholten A, van Tilborg M, de Weys D, Wisse J and Hamersma H. (2008) 11-(pyridinylphenyl)steroids--a new class of mixed-profile progesterone agonists/antagonists. Bioorg Med Chem 16: 2753-63 [PMID:18243712]

290. Richer JK, Jacobsen BM, Manning NG, Abel MG, Wolf DM and Horwitz KB. (2002) Differential gene regulation by the two progesterone receptor isoforms in human breast cancer cells. $J$ Biol Chem 277: 5209-18 [PMID:11717311]

291. Rickard AJ, Morgan J, Bienvenu LA, Fletcher EK, Cranston GA, Shen JZ, Reichelt ME, Delbridge LM and Young MJ. (2012) Cardiomyocyte mineralocorticoid receptors are essential for deoxycorticosterone/salt-mediated inflammation and cardiac fibrosis. Hypertension 60: 1443-50 [PMID:23108646]

292. Rickard AJ, Morgan J, Chrissobolis S, Miller AA, Sobey CG and Young MJ. (2014) Endothelial cell mineralocorticoid receptors regulate deoxycorticosterone/salt-mediated cardiac remodeling and vascular reactivity but not blood pressure. Hypertension 63: 1033-40 [PMID:24566081]

293. Ripa L, Edman K, Dearman M, Edenro G, Hendrickx R, Ullah V, Chang HF, Lepistö M, Chapman D and Geschwindner S et al.. (2018) Discovery of a Novel Oral Glucocorticoid Receptor Modulator (AZD9567) with Improved Side Effect Profile. J Med Chem 61: 1785-1799 [PMID:29424542]

294. Rivers C, Levy A, Hancock J, Lightman S and Norman M. (1999) Insertion of an amino acid in the DNA-binding domain of the glucocorticoid receptor as a result of alternative splicing. J Clin Endocrinol Metab 84: 4283-6 [PMID:10566686]

295. Rižner TL, Brožič P, Doucette C, Turek-Etienne T, Müller-Vieira U, Sonneveld E, van der Burg B, Böcker C and Husen B. (2011) Selectivity and potency of the retroprogesterone dydrogesterone in vitro. Steroids 76: 607-15 [PMID:21376746]

296. Robert-Nicoud M, Flahaut M, Elalouf JM, Nicod M, Salinas M, Bens M, Doucet A, Wincker P, Artiguenave F and Horisberger JD et al.. (2001) Transcriptome of a mouse kidney cortical collecting duct cell line: effects of aldosterone and vasopressin. Proc Natl Acad Sci U S A 98: 2712-6 [PMID:11226305]

297. Robker RL, Russell DL, Espey LL, Lydon JP, O'Malley BW and Richards JS. (2000) Progesteroneregulated genes in the ovulation process: ADAMTS-1 and cathepsin L proteases. Proc Natl Acad Sci USA 97: 4689-94 [PMID:10781075]

298. Roemer SC, Donham DC, Sherman L, Pon VH, Edwards DP and Churchill ME. (2006) Structure of the progesterone receptor-deoxyribonucleic acid complex: novel interactions required for binding to half-site response elements. Mol Endocrinol 20: 3042-52 [PMID:16931575]

299. Rog-Zielinska EA, Thomson A, Kenyon CJ, Brownstein DG, Moran CM, Szumska D, Michailidou Z, Richardson J, Owen E and Watt A et al.. (2013) Glucocorticoid receptor is required for foetal heart maturation. Hum Mol Genet 22: 3269-82 [PMID:23595884]

300. Rogerson FM, Yao YZ, Young MJ and Fuller PJ. (2014) Identification and characterization of a ligand-selective mineralocorticoid receptor coactivator. FASEB J 28: 4200-10 [PMID:24907116]

301. Ronzaud C, Loffing J, Bleich M, Gretz N, Gröne HJ, Schütz G and Berger S. (2007) Impairment of sodium balance in mice deficient in renal principal cell mineralocorticoid receptor. J Am Soc Nephrol 18: 1679-87 [PMID:17475815]

302. Rothhut B, Cloix JF and Russo-Marie F. (1983) Dexamethasone induces the synthesis of "renocortins," two antiphospholipase proteins in rat renomedullary interstitial cells in culture. Adv Prostaglandin Thromboxane Leukot Res 12: 51-6 [PMID:6221639]

303. Rucker PV and Snyder JS.. (2014) Tricyclic compounds, compositions, and methods Patent number: US8901310.

304. Rupprecht R, Reul JM, van Steensel B, Spengler D, Söder M, Berning B, Holsboer F and Damm K. (1993) Pharmacological and functional characterization of human mineralocorticoid and glucocorticoid receptor ligands. Eur J Pharmacol 247: 145-54 [PMID:8282004]

305. Ruzzo EK, Pérez-Cano L, Jung JY, Wang LK, Kashef-Haghighi D, Hartl C, Singh C, Xu J, Hoekstra JN and Leventhal O et al.. (2019) Inherited and De Novo Genetic Risk for Autism Impacts Shared Networks. Cell 178: 850-866.e26 [PMID:31398340]

306. Rüdiger JJ, Roth M, Bihl MP, Cornelius BC, Johnson M, Ziesche R and Block LH. (2002) Interaction of C/EBPalpha and the glucocorticoid receptor in vivo and in nontransformed human cells. FASEB J 16: 177-84 [PMID:11818365]

307. Saartok T, Dahlberg E and Gustafsson JA. (1984) Relative binding affinity of anabolic-androgenic steroids: comparison of the binding to the androgen receptors in skeletal muscle and in prostate, as well as to sex hormone-binding globulin. Endocrinology 114: 2100-6 [PMID:6539197]

308. Saitoh M, Ohmichi M, Takahashi K, Kawagoe J, Ohta T, Doshida M, Takahashi T, Igarashi H, Mori-Abe A, Du B, Tsutsumi S and Kurachi H. (2005) Medroxyprogesterone acetate induces cell proliferation through up-regulation of cyclin D1 expression via phosphatidylinositol 3kinase/Akt/nuclear factor-kappaB cascade in human breast cancer cells. Endocrinology 146: 4917-25 [PMID:16123159]

309. Sartorato P, Cluzeaud F, Fagart J, Viengchareun S, Lombès M and Zennaro MC. (2004) New naturally occurring missense mutations of the human mineralocorticoid receptor disclose 
important residues involved in dynamic interactions with deoxyribonucleic acid, intracellular trafficking, and ligand binding. Mol Endocrinol 18: 2151-65 [PMID:15192075]

310. Scheinman RI, Gualberto A, Jewell CM, Cidlowski JA and Baldwin AS. (1995) Characterization of mechanisms involved in transrepression of NF-kappa B by activated glucocorticoid receptors. Mol Cell Biol 15: 943-53 [PMID:7823959]

311. Scheller A, Scheinman RI, Thompson E, Scarlett CO and Robins DM. (1996) Contextual dependence of steroid receptor function on an androgen-responsive enhancer. Mol Cell Endocrinol 121: 75-86 [PMID:8865168]

312. Schindler AE, Campagnoli C, Druckmann R, Huber J, Pasqualini JR, Schweppe KW and Thijssen JH. (2003) Classification and pharmacology of progestins. Maturitas 46 Suppl 1: S7-S16 [PMID:14670641]

313. Schäcke H, Schottelius A, Döcke WD, Strehlke P, Jaroch S, Schmees N, Rehwinkel H, Hennekes $\mathrm{H}$ and Asadullah K. (2004) Dissociation of transactivation from transrepression by a selective glucocorticoid receptor agonist leads to separation of therapeutic effects from side effects. Proc Natl Acad Sci USA 101: 227-32 [PMID:14694204]

314. Schäcke H, Zollner TM, Döcke WD, Rehwinkel H, Jaroch S, Skuballa W, Neuhaus R, May E, Zügel U and Asadullah K. (2009) Characterization of ZK 245186, a novel, selective glucocorticoid receptor agonist for the topical treatment of inflammatory skin diseases. $\mathrm{Br} J$ Pharmacol 158: 1088-103 [PMID:19422381]

315. Schäfer N, Lohmann C, Winnik S, van Tits LJ, Miranda MX, Vergopoulos A, Ruschitzka F, Nussberger J, Berger S and Lüscher TF et al.. (2013) Endothelial mineralocorticoid receptor activation mediates endothelial dysfunction in diet-induced obesity. Eur Heart J 34: 3515-24 [PMID:23594590]

316. Schüle R, Rangarajan P, Kliewer S, Ransone LJ, Bolado J, Yang N, Verma IM and Evans RM. (1990) Functional antagonism between oncoprotein c-Jun and the glucocorticoid receptor. Cell 62: 1217-26 [PMID:2169353]

317. SEGAL HL and GONZALEZLOPEZ C. (1963) EARLY EFFECTS OF GLUCOCORTICOIDS ON PRECURSOR INCORPORATION INTO GLYCOGEN. Nature 200: 143-4 [PMID:14073027]

318. Shang Y, Myers M and Brown M. (2002) Formation of the androgen receptor transcription complex. Mol Cell 9: 601-10 [PMID:11931767]

319. Shen JZ, Morgan J, Tesch GH, Rickard AJ, Chrissobolis S, Drummond GR, Fuller PJ and Young MJ. (2016) Cardiac Tissue Injury and Remodeling Is Dependent Upon MR Regulation of Activation Pathways in Cardiac Tissue Macrophages. Endocrinology 157: 3213-23 [PMID:27253999]

320. Sheppard HM, Harries JC, Hussain S, Bevan C and Heery DM. (2001) Analysis of the steroid receptor coactivator 1 (SRC1)-CREB binding protein interaction interface and its importance for the function of SRC1. Mol Cell Biol 21: 39-50 [PMID:11113179]

321. Shi Y, Downes M, Xie W, Kao HY, Ordentlich P, Tsai CC, Hon M and Evans RM. (2001) Sharp, an inducible cofactor that integrates nuclear receptor repression and activation. Genes Dev 15: 1140-51 [PMID:11331609]

322. Shibata S, Nagase M, Yoshida S, Kawarazaki W, Kurihara H, Tanaka H, Miyoshi J, Takai Y and Fujita T. (2008) Modification of mineralocorticoid receptor function by Rac1 GTPase: implication in proteinuric kidney disease. Nat Med 14: 1370-6 [PMID:19029984]

323. Shigaev A, Asher C, Latter H, Garty H and Reuveny E. (2000) Regulation of sgk by aldosterone and its effects on the epithelial $\mathrm{Na}(+)$ channel. Am J Physiol Renal Physiol 278: F613-9 [PMID:10751222]

324. Shiozawa T, Shih HC, Miyamoto T, Feng YZ, Uchikawa J, Itoh K and Konishi I. (2003) Cyclic changes in the expression of steroid receptor coactivators and corepressors in the normal human endometrium. J Clin Endocrinol Metab 88: 871-8 [PMID:12574227]

325. Shyamala G, Yang X, Silberstein G, Barcellos-Hoff MH and Dale E. (1998) Transgenic mice carrying an imbalance in the native ratio of A to B forms of progesterone receptor exhibit developmental abnormalities in mammary glands. Proc Natl Acad Sci USA 95: 696-701 [PMID:9435255]

326. Simard J, Singh SM and Labrie F. (1997) Comparison of in vitro effects of the pure antiandrogens $\mathrm{OH}$-flutamide, Casodex, and nilutamide on androgen-sensitive parameters. Urology 49: 580-6; discussion 586-9 [PMID:9111629]

327. Skrabal F, Auböck J, Edwards CR and Braunsteiner H. (1978) Subtraction potential difference: In-vivo assay for mineralocorticoid activity. Lancet 1: 298-302 [PMID:75336]

328. Smith CL, Oñate SA, Tsai MJ and O'Malley BW. (1996) CREB binding protein acts synergistically with steroid receptor coactivator-1 to enhance steroid receptor-dependent transcription. Proc Natl Acad Sci USA 93: 8884-8 [PMID:8799122]

329. Soundararajan R, Pearce D and Ziera T. (2012) The role of the ENaC-regulatory complex in aldosterone-mediated sodium transport. Mol Cell Endocrinol 350: 242-7 [PMID:22101317]

330. Soundararajan R, Zhang TT, Wang J, Vandewalle A and Pearce D. (2005) A novel role for glucocorticoid-induced leucine zipper protein in epithelial sodium channel-mediated sodium 
transport. J Biol Chem 280: 39970-81 [PMID:16216878]

331. Spencer TE, Jenster G, Burcin MM, Allis CD, Zhou J, Mizzen CA, McKenna NJ, Onate SA, Tsai SY, Tsai MJ and O'Malley BW. (1997) Steroid receptor coactivator-1 is a histone acetyltransferase. Nature 389: 194-8 [PMID:9296499]

332. Stephenson G, Krozowski Z and Funder JW. (1984) Extravascular CBG-like sites in rat kidney and mineralocorticoid receptor specificity. Am J Physiol 246: F227-33 [PMID:6320679]

333. Stockand JD, Spier BJ, Worrell RT, Yue G, Al-Baldawi N and Eaton DC. (1999) Regulation of $\mathrm{Na}(+)$ reabsorption by the aldosterone-induced small G protein K-Ras2A. J Biol Chem 274: 35449-54 [PMID:10585415]

334. Stöcklin E, Wissler M, Gouilleux F and Groner B. (1996) Functional interactions between Stat5 and the glucocorticoid receptor. Nature 383: 726-8 [PMID:8878484]

335. Sullivan WP and Toft DO. (1993) Mutational analysis of hsp90 binding to the progesterone receptor. J Biol Chem 268: 20373-9 [PMID:8376394]

336. Sun F, Chen HG, Li W, Yang X, Wang X, Jiang R, Guo Z, Chen H, Huang J and Borowsky AD et al.. (2014) Androgen receptor splice variant AR3 promotes prostate cancer via modulating expression of autocrine/paracrine factors. J Biol Chem 289: 1529-39 [PMID:24297183]

337. Sun S, Sprenger CC, Vessella RL, Haugk K, Soriano K, Mostaghel EA, Page ST, Coleman IM, Nguyen HM and Sun H et al.. (2010) Castration resistance in human prostate cancer is conferred by a frequently occurring androgen receptor splice variant. J Clin Invest 120: 2715-30 [PMID:20644256]

338. Surjit M, Ganti KP, Mukherji A, Ye T, Hua G, Metzger D, Li M and Chambon P. (2011) Widespread negative response elements mediate direct repression by agonist-liganded glucocorticoid receptor. Cell 145: 224-41 [PMID:21496643]

339. Sułek A, Hoffman-Zacharska D, Krysa W, Szirkowiec W, Fidziańska E and Zaremba J. (2005) CAG repeat polymorphism in the androgen receptor (AR) gene of SBMA patients and a control group. J Appl Genet 46: 237-9 [PMID:15876692]

340. Swanson EA, Nelson JW, Jeng S, Erspamer KJ, Yang CL, McWeeney S and Ellison DH. (2019) Salt-sensitive transcriptome of isolated kidney distal tubule cells. Physiol Genomics 51: 125-135 [PMID:30875275]

341. Tajika T, Waki M, Tsuzuki M, Kida T and Sakaki H. (2011) Pharmacokinetic features of difluprednate ophthalmic emulsion in rabbits as determined by glucocorticoid receptor-binding bioassay. J Ocul Pharmacol Ther 27: 29-34 [PMID:21182429]

342. Tajima T, Kitagawa H, Yokoya S, Tachibana K, Adachi M, Nakae J, Suwa S, Katoh S and Fujieda K. (2000) A novel missense mutation of mineralocorticoid receptor gene in one Japanese family with a renal form of pseudohypoaldosteronism type 1. J Clin Endocrinol Metab 85: 4690-4 [PMID:11134129]

343. Takamoto N, Zhao B, Tsai SY and DeMayo FJ. (2002) Identification of Indian hedgehog as a progesterone-responsive gene in the murine uterus. Mol Endocrinol 16: 2338-48 [PMID:12351698]

344. Takeda H, Chodak G, Mutchnik S, Nakamoto T and Chang C. (1990) Immunohistochemical localization of androgen receptors with mono- and polyclonal antibodies to androgen receptor. $J$ Endocrinol 126: 17-25 [PMID:2199591]

345. Tallec LP, Kirsh O, Lecomte MC, Viengchareun S, Zennaro MC, Dejean A and Lombès M. (2003) Protein inhibitor of activated signal transducer and activator of transcription 1 interacts with the N-terminal domain of mineralocorticoid receptor and represses its transcriptional activity: implication of small ubiquitin-related modifier 1 modification. Mol Endocrinol 17: 2529-42 [PMID:14500761]

346. Tan H, Yi L, Rote NS, Hurd WW and Mesiano S. (2012) Progesterone receptor-A and -B have opposite effects on proinflammatory gene expression in human myometrial cells: implications for progesterone actions in human pregnancy and parturition. J Clin Endocrinol Metab 97: E719-30 [PMID:22419721]

347. Tan JA, Joseph DR, Quarmby VE, Lubahn DB, Sar M, French FS and Wilson EM. (1988) The rat androgen receptor: primary structure, autoregulation of its messenger ribonucleic acid, and immunocytochemical localization of the receptor protein. Mol Endocrinol 2: 1276-85 [PMID:3216867]

348. Tan JA, Marschke KB, Ho KC, Perry ST, Wilson EM and French FS. (1992) Response elements of the androgen-regulated C3 gene. J Biol Chem 267: 4456-66 [PMID:1537831]

349. Tanos T, Sflomos G, Echeverria PC, Ayyanan A, Gutierrez M, Delaloye JF, Raffoul W, Fiche M, Dougall W and Schneider P et al.. (2013) Progesterone/RANKL is a major regulatory axis in the human breast. Sci Transl Med 5: 182ra55 [PMID:23616122]

350. Teller MN, Stock CC, Bowie M, Chou TC and Budinger JM. (1982) Therapy of 7,12dimethylbenz(a)anthracene-induced rat mammary carcinomas with combinations of 5fluorouracil and 2 alpha-methyldihydrotestosterone propionate. Cancer Res 42: 4408-12 [PMID:6812946]

351. Terker AS, Yarbrough B, Ferdaus MZ, Lazelle RA, Erspamer KJ, Meermeier NP, Park HJ, 
McCormick JA, Yang CL and Ellison DH. (2016) Direct and Indirect Mineralocorticoid Effects Determine Distal Salt Transport. J Am Soc Nephrol 27: 2436-45 [PMID:26712527]

352. Terry KL, De Vivo I, Titus-Ernstoff L, Sluss PM and Cramer DW. (2005) Genetic variation in the progesterone receptor gene and ovarian cancer risk. Am J Epidemiol 161: 442-51 [PMID:15718480]

353. Tilley WD, Marcelli M, Wilson JD and McPhaul MJ. (1989) Characterization and expression of a cDNA encoding the human androgen receptor. Proc Natl Acad Sci USA 86: 327-31 [PMID:2911578]

354. Tobler A, Meier R, Seitz M, Dewald B, Baggiolini M and Fey MF. (1992) Glucocorticoids downregulate gene expression of GM-CSF, NAP-1/IL-8, and IL-6, but not of M-CSF in human fibroblasts. Blood 79: 45-51 [PMID:1370208]

355. Tomlins SA, Rhodes DR, Perner S, Dhanasekaran SM, Mehra R, Sun XW, Varambally S, Cao X, Tchinda J and Kuefer R et al.. (2005) Recurrent fusion of TMPRSS2 and ETS transcription factor genes in prostate cancer. Science 310: 644-8 [PMID:16254181]

356. Torchia J, Rose DW, Inostroza J, Kamei Y, Westin S, Glass CK and Rosenfeld MG. (1997) The transcriptional co-activator $\mathrm{p} / \mathrm{CIP}$ binds CBP and mediates nuclear-receptor function. Nature 387: 677-84 [PMID:9192892]

357. Tran C, Ouk S, Clegg NJ, Chen Y, Watson PA, Arora V, Wongvipat J, Smith-Jones PM, Yoo D and Kwon A et al.. (2009) Development of a second-generation antiandrogen for treatment of advanced prostate cancer. Science 324: 787-90 [PMID:19359544]

358. Trapp T, Rupprecht R, Castrén M, Reul JM and Holsboer F. (1994) Heterodimerization between mineralocorticoid and glucocorticoid receptor: a new principle of glucocorticoid action in the CNS. Neuron 13: 1457-62 [PMID:7993637]

359. Treviño LS, Bingman 3rd WE, Edwards DP and Nl W. (2013) The requirement for p42/p44 MAPK activity in progesterone receptor-mediated gene regulation is target gene-specific. Steroids 78: 542-7 [PMID:23380370]

360. Tronche F, Kellendonk C, Kretz O, Gass P, Anlag K, Orban PC, Bock R, Klein R and Schütz G. (1999) Disruption of the glucocorticoid receptor gene in the nervous system results in reduced anxiety. Nat Genet 23: 99-103 [PMID:10471508]

361. Tronche F, Opherk C, Moriggl R, Kellendonk C, Reimann A, Schwake L, Reichardt HM, Stangl K, Gau D and Hoeflich A et al.. (2004) Glucocorticoid receptor function in hepatocytes is essential to promote postnatal body growth. Genes Dev 18: 492-7 [PMID:15037546]

362. U M, Shen L, Oshida T, Miyauchi J, Yamada M and Miyashita T. (2004) Identification of novel direct transcriptional targets of glucocorticoid receptor. Leukemia 18: 1850-6 [PMID:15385927]

363. Ueda K, Fujiki K, Shirahige K, Gomez-Sanchez CE, Fujita T, Nangaku M and Nagase M. (2014) Genome-wide analysis of murine renal distal convoluted tubular cells for the target genes of mineralocorticoid receptor. Biochem Biophys Res Commun 445: 132-7 [PMID:24491541]

364. van de Wijngaart DJ, Dubbink HJ, Molier M, de Vos C, Trapman J and Jenster G. (2009) Functional screening of FxxLF-like peptide motifs identifies SMARCD1/BAF60a as an androgen receptor cofactor that modulates TMPRSS2 expression. Mol Endocrinol 23: 1776-86 [PMID:19762545]

365. van den Heuvel JK, Boon MR, van Hengel I, Peschier-van der Put E, van Beek L, van Harmelen V, van Dijk KW, Pereira AM, Hunt $\mathrm{H}$ and Belanoff JK et al.. (2016) Identification of a selective glucocorticoid receptor modulator that prevents both diet-induced obesity and inflammation. $\mathrm{Br}$ J Pharmacol 173: 1793-804 [PMID:26990179]

366. van Leeuwen N, Caprio M, Blaya C, Fumeron F, Sartorato P, Ronconi V, Giacchetti G, Mantero F, Fernandes-Rosa FL and Simian C et al.. (2010) The functional c.-2G $>$ C variant of the mineralocorticoid receptor modulates blood pressure, renin, and aldosterone levels. Hypertension 56: 995-1002 [PMID:20855654]

367. van Lierop MJ, Alkema W, Laskewitz AJ, Dijkema R, van der Maaden HM, Smit MJ, Plate R, Conti PG, Jans CG and Timmers CM et al.. (2012) Org 214007-0: a novel non-steroidal selective glucocorticoid receptor modulator with full anti-inflammatory properties and improved therapeutic index. PLoS One 7: e48385 [PMID:23152771]

368. van Weert LTCM, Buurstede JC, Mahfouz A, Braakhuis PSM, Polman JAE, Sips HCM, Roozendaal B, Balog J, de Kloet ER and Datson NA et al.. (2017) NeuroD Factors Discriminate Mineralocorticoid From Glucocorticoid Receptor DNA Binding in the Male Rat Brain. Endocrinology 158: 1511-1522 [PMID:28324065]

369. Vegeto E, Shahbaz MM, Wen DX, Goldman ME, O'Malley BW and McDonnell DP. (1993) Human progesterone receptor A form is a cell- and promoter-specific repressor of human progesterone receptor B function. Mol Endocrinol 7: 1244-55 [PMID:8264658]

370. Verrey F. (1999) Early aldosterone action: toward filling the gap between transcription and transport. Am J Physiol 277: F319-27 [PMID:10484514]

371. Verrijdt G, Haelens A, Schoenmakers E, Rombauts W and Claessens F. (2002) Comparative analysis of the influence of the high-mobility group box 1 protein on DNA binding and transcriptional activation by the androgen, glucocorticoid, progesterone and mineralocorticoid 
receptors. Biochem J 361: 97-103 [PMID:11742533]

372. Verrijdt G, Schoenmakers E, Alen P, Haelens A, Peeters B, Rombauts W and Claessens F. (1999) Androgen specificity of a response unit upstream of the human secretory component gene is mediated by differential receptor binding to an essential androgen response element. Mol Endocrinol 13: 1558-70 [PMID:10478846]

373. Voegel JJ, Heine MJ, Tini M, Vivat V, Chambon P and Gronemeyer H. (1998) The coactivator TIF2 contains three nuclear receptor-binding motifs and mediates transactivation through CBP binding-dependent and -independent pathways. EMBO J 17: 507-19 [PMID:9430642]

374. von Geldern TW, Tu N, Kym PR, Link JT, Jae HS, Lai C, Apelqvist T, Rhonnstad P, Hagberg L and Koehler K et al.. (2004) Liver-selective glucocorticoid antagonists: a novel treatment for type 2 diabetes. J Med Chem 47: 4213-30 [PMID:15293993]

375. Vottero A, Kino T, Combe H, Lecomte P and Chrousos GP. (2002) A novel, C-terminal dominant negative mutation of the GR causes familial glucocorticoid resistance through abnormal interactions with p160 steroid receptor coactivators. J Clin Endocrinol Metab 87: 2658-67 [PMID:12050230]

376. Waage A. (1987) Production and clearance of tumor necrosis factor in rats exposed to endotoxin and dexamethasone. Clin Immunol Immunopathol 45: 348-55 [PMID:3315338]

377. Wagner BL, Norris JD, Knotts TA, Weigel NL and McDonnell DP. (1998) The nuclear corepressors NCoR and SMRT are key regulators of both ligand- and 8-bromo-cyclic AMPdependent transcriptional activity of the human progesterone receptor. Mol Cell Biol 18: 136978 [PMID:9488452]

378. Wakabayashi K, Imai K, Miyachi H, Hashimoto Y and Tanatani A. (2008) 4-(Anilino)pyrrole-2carboxamides: Novel non-steroidal/non-anilide type androgen antagonists effective upon human prostate tumor LNCaP cells with mutated nuclear androgen receptor. Bioorg Med Chem 16: 6799-812 [PMID:18571420]

379. Walker BR, Andrew R, Escoubet B and Zennaro MC. (2014) Activation of the hypothalamicpituitary-adrenal axis in adults with mineralocorticoid receptor haploinsufficiency. J Clin Endocrinol Metab 99: E1586-91 [PMID:24712576]

380. Wang JC, Derynck MK, Nonaka DF, Khodabakhsh DB, Haqq C and Yamamoto KR. (2004) Chromatin immunoprecipitation (ChIP) scanning identifies primary glucocorticoid receptor target genes. Proc Natl Acad Sci USA 101: 15603-8 [PMID:15501915]

381. Wang LG, Liu XM, Kreis W and Budman DR. (1998) Androgen antagonistic effect of estramustine phosphate (EMP) metabolites on wild-type and mutated androgen receptor. Biochem Pharmacol 55: 1427-33 [PMID:10076535]

382. Wang Q, Anzick S, Richter WF, Meltzer P and Simons SS. (2004) Modulation of transcriptional sensitivity of mineralocorticoid and estrogen receptors. J Steroid Biochem Mol Biol 91: 197-210 [PMID:15336697]

383. Wang Q, Li W, Liu XS, Carroll JS, Jänne OA, Keeton EK, Chinnaiyan AM, Pienta KJ and Brown M. (2007) A hierarchical network of transcription factors governs androgen receptor-dependent prostate cancer growth. Mol Cell 27: 380-92 [PMID:17679089]

384. Wardell SE, Boonyaratanakornkit V, Adelman JS, Aronheim A and Edwards DP. (2002) Jun dimerization protein 2 functions as a progesterone receptor $\mathrm{N}$-terminal domain coactivator. $\mathrm{Mol}$ Cell Biol 22: 5451-66 [PMID:12101239]

385. Webster JC, Pedersen NR, Edwards DP, Beck CA and Miller WL. (1995) The 5'-flanking region of the ovine follicle-stimulating hormone-beta gene contains six progesterone response elements: three proximal elements are sufficient to increase transcription in the presence of progesterone. Endocrinology 136: 1049-58 [PMID:7867558]

386. Wei Q, Lu XY, Liu L, Schafer G, Shieh KR, Burke S, Robinson TE, Watson SJ, Seasholtz AF and Akil H. (2004) Glucocorticoid receptor overexpression in forebrain: a mouse model of increased emotional lability. Proc Natl Acad Sci USA 101: 11851-6 [PMID:15280545]

387. WEST KM. (1959) Response of the blood glucose to glucocorticoids in man; determination of the hyperglycemic potencies of glucocorticoids. Diabetes 8: 22-8 [PMID:13619487]

388. Wilson CM and McPhaul MJ. (1994) A and B forms of the androgen receptor are present in human genital skin fibroblasts. Proc Natl Acad Sci USA 91: 1234-8 [PMID:8108393]

389. Wilson CM and McPhaul MJ. (1996) A and B forms of the androgen receptor are expressed in a variety of human tissues. Mol Cell Endocrinol 120: 51-7 [PMID:8809738]

390. Wong S, Brennan FE, Young MJ, Fuller PJ and Cole TJ. (2007) A direct effect of aldosterone on endothelin-1 gene expression in vivo. Endocrinology 148: 1511-7 [PMID:17218419]

391. Yang J, Fuller PJ, Morgan J, Shibata H, Clyne CD and Young MJ. (2015) GEMIN4 functions as a coregulator of the mineralocorticoid receptor. J Mol Endocrinol 54: 149-60 [PMID:25555524]

392. Yang J, Fuller PJ, Morgan J, Shibata H, McDonnell DP, Clyne CD and Young MJ. (2014) Use of phage display to identify novel mineralocorticoid receptor-interacting proteins. Mol Endocrinol 28: 1571-84 [PMID:25000480]

393. Yang-Yen HF, Chambard JC, Sun YL, Smeal T, Schmidt TJ, Drouin J and Karin M. (1990) Transcriptional interference between c-Jun and the glucocorticoid receptor: mutual inhibition of 
DNA binding due to direct protein-protein interaction. Cell 62: 1205-15 [PMID:2169352]

394. Ye X, Han SJ, Tsai SY, DeMayo FJ, Xu J, Tsai MJ and O'Malley BW. (2005) Roles of steroid receptor coactivator (SRC)-1 and transcriptional intermediary factor (TIF) 2 in androgen receptor activity in mice. Proc Natl Acad Sci USA 102: 9487-92 [PMID:15983373]

395. Yeh S, Sampson ER, Lee DK, Kim E, Hsu CL, Chen YL, Chang HC, Altuwaijri S, Huang KE and Chang C. (2000) Functional analysis of androgen receptor N-terminal and ligand binding domain interacting coregulators in prostate cancer. J Formos Med Assoc 99: 885-94 [PMID:11155740]

396. Yin D, Gao W, Kearbey JD, Xu H, Chung K, He Y, Marhefka CA, Veverka KA, Miller DD and Dalton JT. (2003) Pharmacodynamics of selective androgen receptor modulators. J Pharmacol Exp Ther 304: 1334-40 [PMID:12604714]

397. Yokota K, Shibata H, Kurihara I, Kobayashi S, Suda N, Murai-Takeda A, Saito I, Kitagawa H, Kato S and Saruta T et al.. (2007) Coactivation of the N-terminal transactivation of mineralocorticoid receptor by Ubc9. J Biol Chem 282: 1998-2010 [PMID:17105732]

398. Yoneda Y, Han D, Ogita K and Watanabe A. (1995) Distinction between binding of $[3 \mathrm{H}]$ triamcinolone acetonide to a ligand binding domain on the glucocorticoid receptor complex in cytosol fractions of brain and liver from the rat with intact adrenals. Brain Res 685: 105-16 [PMID:7583234]

399. Yong W, Yang Z, Periyasamy S, Chen H, Yucel S, Li W, Lin LY, Wolf IM, Cohn MJ and Baskin LS et al.. (2007) Essential role for Co-chaperone Fkbp52 but not Fkbp51 in androgen receptormediated signaling and physiology. J Biol Chem 282: 5026-36 [PMID:17142810]

400. Yu C, Yap N, Chen D and Cheng S. (1997) Modulation of hormone-dependent transcriptional activity of the glucocorticoid receptor by the tumor suppressor p53. Cancer Lett 116: 191-6 [PMID:9215863]

401. Yuan J, Jia R and Bao Y. (2007) Aldosterone up-regulates production of plasminogen activator inhibitor-1 by renal mesangial cells. J Biochem Mol Biol 40: 180-8 [PMID:17394767]

402. Yudt MR, Russo LA, Berrodin TJ, Jelinsky SA, Ellis D, Cohen JC, Cooch N, Haglund E, Unwalla RJ and Fensome A et al.. (2011) Discovery of a novel mechanism of steroid receptor antagonism: WAY-255348 modulates progesterone receptor cellular localization and promoter interactions. Biochem Pharmacol 82: 1709-19 [PMID:21854761]

403. Zennaro MC and Fernandes-Rosa F. (2017) 30 YEARS OF THE MINERALOCORTICOID RECEPTOR: Mineralocorticoid receptor mutations. J Endocrinol 234: T93-T106 [PMID:28348114]

404. Zennaro MC, Souque A, Viengchareun S, Poisson E and Lombès M. (2001) A new human MR splice variant is a ligand-independent transactivator modulating corticosteroid action. Mol Endocrinol 15: 1586-98 [PMID:11518808]

405. Zhang S, Murtha PE and Young CY. (1997) Defining a functional androgen responsive element in the 5' far upstream flanking region of the prostate-specific antigen gene. Biochem Biophys Res Commun 231: 784-8 [PMID:9070893]

406. Zhang Z, Funk C, Roy D, Glasser S and Mulholland J. (1994) Heparin-binding epidermal growth factor-like growth factor is differentially regulated by progesterone and estradiol in rat uterine epithelial and stromal cells. Endocrinology 134: 1089-94 [PMID:8119147]

407. Zhang Z, Jones S, Hagood JS, Fuentes NL and Fuller GM. (1997) STAT3 acts as a co-activator of glucocorticoid receptor signaling. J Biol Chem 272: 30607-10 [PMID:9388192]

408. Zhi L, Ringgenberg JD, Edwards JP, Tegley CM, West SJ, Pio B, Motamedi M, Jones TK, Marschke KB and Mais DE et al.. (2003) Development of progesterone receptor antagonists from 1,2-dihydrochromeno[3,4-f]quinoline agonist pharmacophore. Bioorg Med Chem Lett 13: 2075-8 [PMID:12781198]

409. Zhi L, Tegley CM, Kallel EA, Marschke KB, Mais DE, Gottardis MM and Jones TK. (1998) 5-Aryl1,2-dihydrochromeno[3,4-f]quinolines: a novel class of nonsteroidal human progesterone receptor agonists. $J$ Med Chem 41: 291-302 [PMID:9464360]

410. Zhi L, Tegley CM, Pio B, Edwards JP, Jones TK, Marschke KB, Mais DE, Risek B and Schrader WT. (2003) Synthesis and biological activity of 5-methylidene 1,2-dihydrochromeno[3,4f]quinoline derivatives as progesterone receptor modulators. Bioorg Med Chem Lett 13: 2071-4 [PMID:12781197]

411. Zhou MY, Gomez-Sanchez CE and Gomez-Sanchez EP. (2000) An alternatively spliced rat mineralocorticoid receptor mRNA causing truncation of the steroid binding domain. Mol Cell Endocrinol 159: 125-31 [PMID:10687858]

412. Zhou XE, Suino-Powell KM, Li J, He Y, Mackeigan JP, Melcher K, Yong EL and Xu HE. (2010) Identification of SRC3/AIB1 as a preferred coactivator for hormone-activated androgen receptor. J Biol Chem 285: 9161-71 [PMID:20086010]

413. Ziera T, Irlbacher H, Fromm A, Latouche C, Krug SM, Fromm M, Jaisser F and Borden SA. (2009) Cnksr3 is a direct mineralocorticoid receptor target gene and plays a key role in the regulation of the epithelial sodium channel. FASEB J 23: 3936-46 [PMID:19567370]

414. Zierau O, Kolodziejczyk A, Vollmer G, Machalz D, Wolber G, Thieme D and Keiler AM. (2019) Comparison of the three SARMs RAD-140, GLPG0492 and GSK-2881078 in two different in vitro 
bioassays, and in an in silico androgen receptor binding assay. J Steroid Biochem Mol Biol 189:

81-86 [PMID:30825507] 